\title{
PETROLOGY AND GEOCHEMISTRY OF BONINITE SERIES VOLCANIC ROCKS, CHICHI-JIMA, BONIN ISLANDS, JAPAN
}

\author{
P.F. Dobson \\ Earth Sciences Division, Lawrence Berkeley National Laboratory, Berkeley, California 94720 \\ S. Maruyama \\ Department of Earth and Planetary Sciences, Tokyo Institute of Technology, Meguro-ku, Tokyo 152-8551, Japan
}

J.G. Blank

Center for the Study of Life in the Universe, SETI Institute, 515 N. Whisman Road, Mountain View, California 94043

J.G. Liou

Department of Geological and Environmental Sciences, Stanford University, Stanford, California 94305

\begin{abstract}
An Eocene submarine boninite series volcanic center is exposed on the island of Chichi-jima, Bonin Islands, Japan. Five rock types, boninite, bronzite andesite, dacite, quartz dacite, and rhyolite, were distinguished within the boninite volcanic sequence on the basis of petrographic and geochemical observations. Boninite lavas contain high magnesium, nickel, and chromium contents indicative of primitive melts, but have high silica contents relative to other mantlederived magmas. All boninite series lavas contain very low incompatible element concentrations, and concentrations of high-field strength elements in primitive boninite lavas are less than half of those found in depleted mid-ocean ridge basalts. Abundances of large-ion lithophile elements are relatively high in boninite series lavas, similar to the enrichments observed in many island arc lavas. Trends for both major and trace element data suggest that the more evolved lavas of the boninite magma series were derived primarily through high-level fractional crystallization of boninite. Textural features, such as resorption and glomeroporphyrocrysts, and reverse chemical zonations suggest that magma mixing contributed to the development of the quartz dacite lavas.
\end{abstract}

\section{Introduction}

A well exposed sequence of Eocene boninite series volcanic rocks are found on Chichi-jima (Figure 1), the type locality for boninites (Peterson, 1891). Earlier geologic studies identified four lithologic units, the Marubewan, Asahiyama, Mikazukiyama, and Minamizaki Formations (e.g., Umino, 1985). The oldest exposed rocks on Chichijima consist of gently dipping boninite pillow lavas that form the lowermost part of the Marubewan Formation. These lavas grade up into intercalated boninitic to dacitic pillow lavas, hyaloclastites, and volcaniclastic horizons. Stratigraphically overlying these rocks are exposures of quartz-bearing dacites and rhyolites of the Asahiyama Formation, the most differentiated members of the boninitic volcanic suite. A sequence of volcaniclastic sediments, the Mikazukiyama Formation, is exposed on the northwest part of Chichi-jima. Massive Oligocene to early Miocene limestones of the Minamizaki Formation unconformably overlie dacitic lavas of the Marubewan Formation on the southwestern tip of Chichi-jima.

This paper summarizes the results of petrographic and geochemical studies of boninite series volcanic rocks from Chichi-jima, and evaluates models for boninite genesis on the basis of these data. The petrography of the five major volcanic rock types, boninite, bronzite andesite, dacite, quartz dacite, and rhyolite is described, and bulk-rock major and trace element geochemical data are presented. Mineral chemistry determined through extensive microprobe analysis is described and discussed, and finally, models evaluating the petrogenesis of boninite and the differentiation of the boninite suite are presented.

\section{Analytical Procedures}

Detailed descriptions of more than 250 thin sections were obtained using a petrographic microscope. Over 40 wholerock samples were analyzed for major and trace element compositions using a Rigaku wavelength dispersive XRF spectrometer. Major elements were analyzed using the fused disc method, and pressed pellets were utilized for trace element analysis. A Kevex energy dispersive XRF spectrometer was used for Ba analyses. Glass and mineral analyses (from polished thin sections) were performed on a 5-spectrometer JEOL microprobe. Analytical runs were made using 
an accelerating voltage of $15 \mathrm{kV}$ and a beam current of $15 \mathrm{nA}$. Alkali loss for the glasses was minimized by using a beam size of 30 microns and a 20 -second counting time. Most mineral microprobe analyses were conducted using a beam size of 10 microns and counting times ranging from 20 to 40 seconds. The reported glass data represent the average of 10 spot analyses for each sample. CIPW normative compositions were calculated assuming a $\mathrm{Fe}_{2} \mathrm{O}_{3} / \mathrm{FeO}$ (wt. \%) ratio of 0.15 .

\section{Petrographic Descriptions of Boninite-Series Rocks}

Five distinct volcanic rock types were identified within the boninite series volcanic sequence. Boninite, bronzite andesite, and dacite lavas were observed in the Marubewan Formation, and quartz-bearing dacites and rhyolites comprise the lithologies of the Asahiyama Formation. Many of these lava compositions are found in a variety of volcanic morphologies and structures, and these different eruptive types control to a certain extent the crystal contents and textures of the lavas.

\section{Boninite}

Boninite lavas are the most primitive rock type of the boninite magma series. Boninite lavas on Chichi-jima occur as dikes, pillowed and sheet flows, and as clasts in breccia and hyaloclastite horizons. Intercalated with bronzite andesite and dacite volcanic rocks throughout the Marubewan Formation, boninite lavas are characterized petrographically by the presence of bronzite phenocrysts and the complete absence of plagioclase. Olivine, clinoenstatite (an inverted form of protoenstatite), and clinopyroxene are common phenocrysts. Pigeonite is present as a groundmass phase in some boninite lavas. Reddish-brown chromium spinel is a ubiquitous accessory phase, occurring as inclusions in olivine and pyroxene. The relative order of crystallization is spinel $\rightarrow$ olivine + clinoenstatite $\rightarrow$ bronzite $\rightarrow$ clinopyroxene $\rightarrow$ pigeonite. Boninites may be relatively aphyric ( $<1 \%$ phenocrysts) or porphyritic ( 1 to $\geq 50 \%$ phenocrysts), and can have a variety of microphenocryst assemblages that reflect variable degrees of magma differentiation and/or magma mixing (Umino, 1986).

Textural features are strongly controlled by the eruptive and cooling histories of the lavas. Rapidly quenched pillow rims contain abundant well-preserved fresh isotropic glass, whereas pillow cores and sheet flows have devitrified groundmass and are more crystalline. Abundant quench crystals of orthopyroxene and, to a lesser degree, clinopyroxene, are found in glassy pillow rims, and display skeletal or feathery morphologies (Figure 2; also Kikuchi, 1890). All lavas are somewhat vesicular, but the extent of vesiculation varies from less than $1 \%$ in pillow lavas at low stratigraphic levels to greater than $30 \%$ in pillow fragments found in pillow breccia horizons. This increase in vesicularity of pillowed flows upsection may reflect accompanying increases in volatile contents of the magma, in part due to higher degrees of crystallinity, as well as decreasing eruption depths through time.

While quenched pillow rims are characteristically less crystal-rich than corresponding cores, the relative and absolute abundances of phenocrysts varies substantially between flows. At Hakohama (see Figure 1 for locality names and sample locations), pillow lava rims from the lowermost part of the sequence contain less than one percent phenocrysts with grain sizes greater than $1 \mathrm{~mm}$ in length, but are comprised of $50 \%$ microphenocrysts of elongate interlocking laths of clinoenstatite and bronzite in a glassy groundmass. These microphenocrysts often form bowtie intergrowths. Upsection, boninite pillow lavas vary between being non to slightly porphyritic ( 1 to $7 \%$ phenocrysts) to being highly porphyritic (20-25\% phenocrysts). Porphyritic lavas contain primarily prismatic bronzite phenocrysts, up to 3 mm in length. Occasionally a thin layer of clinopyroxene rims these crystals. Some of the long prismatic clinoenstatite crystals reach $4 \mathrm{~mm}$ in length.

More clinopyroxene-rich boninites are found in pillowed lava flows near Sakaiura. These rocks contain approximately $10 \%$ orthopyroxene and $4 \%$ clinopyroxene phenocrysts $(1-2 \mathrm{~mm})$ occurring in crystal clumps. Orthopyroxene crystals contain numerous glass and opaque inclusions, giving them a sieved texture; some are rimmed by clinopyroxene. These features are common in most bronzite crystals in boninite and bronzite andesite lavas.

Olivine-bearing boninite pillow lavas and dikes are present on the east coast of Chichi-jima near Ishiura. Although most of the olivine crystals have been altered to fine-grained smectite and serpentine minerals, relict cores are found within the euhedral crystal pseudomorphs. Olivine-bearing boninite clasts also occur in breccia horizons. 
The freshest boninite lavas were found in steep sea-cliff exposures on the southern coast near Kamenokubi. These rocks contain about $5 \%$ bronzite phenocrysts with minor clinoenstatite and clinopyroxene phenocrysts. Most clinoenstatite crystals are rimmed by thin orthopyroxene growths. The glassy groundmass contains an additional $20 \%$ of microphenocrysts and quench crystals of orthopyroxene and clinopyroxene.

The extent of alteration of boninite lavas varies widely. Samples that contain few vesicles tend to be less altered than highly vesicular samples. Calcite, silica and a variety of zeolites fill most vesicles (Nishido and Otsuka, 1981; 1982), and calcite, quartz, and palagonite veins cut some lavas. Palagonitization tends to occur along fractures and vesicle walls that serve as conduits for the passage of circulating fluids. While some glassy samples are virtually unaffected by palagonitization (e.g. MD-94, 97 near Kamenokubi), more vesicular pillow lavas, such as MD-147 (near Sakaiura), have been highly altered. In such altered samples, not only has the groundmass undergone secondary mineralization, but also pyroxene and olivine crystals are partially to thoroughly replaced by fine-grained clay minerals.

\section{Bronzite Andesite}

Bronzite andesites are very similar to more primitive boninite lavas, but differ petrographically in that they contain plagioclase and lack olivine. These rocks contain abundant bronzite phenocrysts and have chromium spinel as an accessory phase. Clinopyroxene is more abundant in these lavas, and pigeonite is sometimes found as a groundmass phase. Plagioclase is present only as a groundmass phase in the more primitive of these lavas. In the more differentiated bronzite andesites, several percent phenocrysts and even more abundant microphenocrysts of plagioclase are present. The crystallization sequence of these lavas is similar to that of boninite, with the relative order spinel $\rightarrow$ clinoenstatite $\rightarrow$ bronzite $\rightarrow$ clinopyroxene $\rightarrow$ plagioclase observed.

Bronzite andesite lavas have the same eruptive morphologies as those observed for boninite volcanic rocks, and exhibit many similar textural features. Quench textures occur in most glassy chilled pillow rims. A wide range in vesiculation is observed in bronzite andesite lavas, which correlates crudely with stratigraphy. One important textural feature common to many bronzite andesite lavas is the presence of crystal clumps of clinopyroxene and plagioclase. These glomeroporphyrocrysts are suggestive of magma mixing or crystal settling processes.

Bronzite andesite lavas span a fairly wide compositional range. Some samples (e.g. MD-16, 31 near Manjumisaki) contain only minor (1-2\%) amounts of plagioclase in the groundmass, and appear in all other respects to be similar to boninite lavas. Slightly more differentiated samples (e.g. MD-108 near Kominato) contain small amounts (1\%) of tabular plagioclase $(1.5 \mathrm{~mm})$ in crystal clumps with clinopyroxene, and have more abundant laths of plagioclase in the groundmass, but still have bronzite as the dominant mineral phase. Finally, some bronzite andesite lavas (e.g. MD-48 near Nagasaki) contain substantial amounts of plagioclase along with abundant clinopyroxene, again as

glomeroporphyritic clots. The presence of these clumps of plagioclase and clinopyroxene, along with the occurrence of clinoenstatite phenocrysts, rimmed by orthopyroxene, suggest that some crystal settling or magma mixing within the boninite magma suite may have occurred. Bronzite continues to be the dominant phenocrystic phase in these lavas, but plagioclase is the primary groundmass mineral.

The styles of alteration of bronzite andesite lavas are similar to those described for boninite lavas. Most vesicles are often filled with calcite, silica, and a number of zeolite phases. Glassy lavas range widely in the degree of palagonitization, and almost all pillow cores and sheet flows have been devitrified. In bronzite andesite sheet flows (MD-17 to 27 near Manjumisaki), not only has the groundmass undergone extensive alteration, but also most of the pyroxene phenocrysts have been altered to clay minerals.

\section{Dacite}

Dacites of the Marubewan Formation occur as dikes, as massive and pillowed lavas, as well as clasts in breccias. These glassy, vesicular lavas contain small $(\sim 1 \mathrm{~mm})$ phenocrysts of plagioclase, orthopyroxene, clinopyroxene, and magnetite. More differentiated dacites contain ferropigeonite instead of orthopyroxene. All dacites contain less than 5 $\%$ phenocrysts, but contain abundant laths of plagioclase in the glassy groundmass. The crystallization sequence observed in these lavas is magnetite $\rightarrow$ pyroxene + plagioclase. 
Flow foliation is often defined by aligned elongate vesicles (1-6\%), and groundmass plagioclase frequently displays trachytic texture. The glassy groundmass often contains perlitic cracks diagnostic of hydration. Phenocrysts commonly occur as glomeroporphyritic clumps.

The dacite lavas are often less visibly altered than more mafic rocks. Glassy samples are often oxidized, but the glass is not commonly altered. Dikes and massive flows have undergone devitrification, but both rims and cores of pillowed lavas are usually glassy. Quartz and calcite veins filling cooling cracks often cut dacite lava flows and dikes, and the vesicles are usually lined with secondary clay mineralization.

\section{Quartz Dacite and Rhyolite}

Quartz dacites of the Asahiyama Formation commonly occur as sheeted lava flows. These rocks contain plagioclase, quartz, orthopyroxene, clinopyroxene, and magnetite phenocrysts in a glassy to devitrified groundmass. The phenocrysts comprise about 15 volume $\%$ of the rock, and consist predominantly of plagioclase and quartz, in a ratio of $2: 1$. All phenocrysts are less than $5 \mathrm{~mm}$ in length. Mafic phenocrysts make up only $1-2 \%$ of the rock. Numerous plagioclase microlites are present in the groundmass. These lavas have the crystallization sequence magnetite $\rightarrow$ pyroxene + plagioclase $\rightarrow$ quartz.

These lavas have some very distinctive textural features (Figure 3). All quartz phenocrysts are strongly resorbed indicating disequilibrium with the melt. Some plagioclase and pyroxene crystals have striking optical zonations, and most plagioclase phenocrysts have corroded and frittered cores containing numerous glass inclusions and have optically distinct outer rims. Magnetite crystals also have somewhat rounded shapes. Orthopyroxene, clinopyroxene, plagioclase and magnetite crystals form glomeroporphyritic clusters, but quartz is never found in these aggregates. All of these features strongly suggest that this rock contains a non-equilibrium mineral assemblage. These lavas also have some flow foliation features, with elongated vesicles ( $2-5 \%$ vesicular) crudely aligned and plagioclase microlites defining a trachytic texture.

Rhyolite comprises the other lithology found within the Asahiyama Formation. It occurs as dikes and as blocky to massive flows, and contains 10 to $25 \%$ phenocrysts in a glassy to devitrified groundmass. It has the same mineral assemblage as that observed for the quartz dacite: quartz, plagioclase, clinopyroxene, orthopyroxene, and magnetite. Plagioclase $(1 \mathrm{~mm})$ and quartz $(1-5 \mathrm{~mm})$ are the dominant phenocryst phases, but in contrast to the dacitic lavas, quartz exceeds plagioclase $2: 1$. The observed crystallization sequence for this rock type is magnetite $\rightarrow$ pyroxene + plagioclase $\rightarrow$ quartz. No potassium feldspar was observed in any of the thin sections examined.

Quartz phenocrysts $(3 \mathrm{~mm})$ also have corroded rims, but often contain overgrowth rims of plagioclase and quartz. Plagioclase crystals contain glass and magnetite inclusions, giving them a sieved texture, but do not have the frittered textures characteristic of many feldspars seen in the quartz dacite. Pyroxene, plagioclase, and magnetite crystals often form crystal clots. Glassy samples have perlitic cracks, and well-defined spherulitic textures are present in some devitrified samples. Vesicles comprise $1-5 \%$ of the rock, and have elongate but irregular shapes that define flow foliation along with oxidation color bands and trachytic texture.

Alteration in these rocks is very similar to that observed in dacitic lavas of the Asahiyama Formation. Veins of calcite and quartz cut these rocks, and vesicle walls are often lined with fine-grained clay minerals. Glass is commonly oxidized or devitrified to some degree. Perlitic cracks in some samples indicate that these rocks have undergone expansion during hydration.

\section{Whole-rock and Glass Geochemistry}

\section{Major element variation}

The major element compositions of boninite series volcanic rocks are given in Table 1. To show geochemical trends with differentiation, oxides, calculated from analyses recast to $100 \%$ anhydrous, are plotted against the magnesium number $\left(\mathrm{Mg} \#=\left\{100 \mathrm{MgO} /\left(\mathrm{MgO}+\mathrm{FeO}^{*}\right)\right\}\right.$ molar $)$ in Figure 4, where $\mathrm{FeO} *$ total $\mathrm{Fe}$ as $\mathrm{FeO} . \mathrm{SiO}_{2}, \mathrm{~K}_{2} \mathrm{O}, \mathrm{Na}_{2} \mathrm{O}$, and $\mathrm{P}_{2} \mathrm{O}_{5}$ all increase with decreasing $\mathrm{Mg}$ number. $\mathrm{TiO}_{2}, \mathrm{Fe}_{2} \mathrm{O}_{3}$ * (total iron as $\mathrm{Fe}_{2} \mathrm{O}_{3}$ ), $\mathrm{MnO}, \mathrm{Al}_{2} \mathrm{O}_{3}$, and $\mathrm{CaO}$ increase or are nearly constant initially, but decline in concentration with increasing differentiation. Glasses are more differentiated than their associated whole-rock samples, but the microprobe analyses for most glass samples (Table 2) correspond 
well with the trends defined by the whole-rock data. One glass sample analyzed (MS-53) is a crystal-rich boninite. The glass is depleted in $\mathrm{Mg}$ relative to $\mathrm{Fe}$ due to pyroxene and olivine crystallization, and thus the glass compositions plotted versus Mg number for this sample lie far off of the whole-rock trends (Figure 4).

Some scatter within these diagrams can be attributed to alteration and crystal settling effects. Some boninite samples have relatively low totals $(<95.5 \%)$ due to alteration, and thus have a wide range in mobile element $(\mathrm{Na}, \mathrm{K}$, and $\mathrm{Ca})$ concentrations. MD-71 has much lower $\mathrm{SiO}_{2}$ and higher $\mathrm{MgO}$ contents than other boninite lavas, and this is likely due to accumulation of abundant (now altered) olivine. Hydration and devitrification of silicic lavas has resulted in widely varying alkali contents and increases in silica.

Boninite and bronzite andesite form a consistent geochemical series. Anhydrous whole-rock analyses of fresh samples increase in $\mathrm{SiO}_{2}\left(56.1 \rightarrow 59.5\right.$ wt. \%), $\mathrm{Al}_{2} \mathrm{O}_{3}(10.4 \rightarrow 14.5), \mathrm{TiO}_{2}(0.11 \rightarrow 0.23), \mathrm{P}_{2} \mathrm{O}_{5}(0.02 \rightarrow 0.04), \mathrm{Na}_{2} \mathrm{O}(1.5 \rightarrow 2.6)$, and $\mathrm{K}_{2} \mathrm{O}(0.45 \rightarrow 0.60)$ with differentiation from boninite to bronzite andesite. Small change is seen in $\mathrm{MnO}(0.14-0.12)$, $\mathrm{Fe}_{2} \mathrm{O}_{3} *$ (8.8-9.3), and $\mathrm{CaO}$ (7.8-8.7) over this compositional range, but a sharp decrease in $\mathrm{MgO}(14.2 \rightarrow 5.4)$ is observed. These trends are consistent with fractionation of orthopyroxene, clinopyroxene, and olivine as principal phases. The moderate increase in silica and slight increase of $\mathrm{CaO}$ over this compositional range strongly suggests that orthopyroxene is the dominant fractionating phase, agreeing well with petrographic observations. The sharp increase in alumina content and the absence of abundant plagioclase phenocrysts in these lavas indicates that plagioclase is not involved in fractionation at this early stage.

A distinct geochemical gap is present between bronzite andesite and dacite whole-rock compositions. This gap is bridged by bronzite andesite glass compositions and quartz dacite whole-rock samples which define inflection points for a number of geochemical trend lines between $\mathrm{Mg}$ numbers 45 and 35. These changes in slope mark the onset of new fractionating phases. The decreases in $\mathrm{Al}_{2} \mathrm{O}_{3}$ and $\mathrm{CaO}$ at $\mathrm{Mg} \# 45$ and in $\mathrm{Fe}_{2} \mathrm{O}_{3}{ }^{*}, \mathrm{MnO}$, and $\mathrm{TiO}_{2}$ at $\mathrm{Mg} \# 35$ signal the increased importance of plagioclase and magnetite as fractionating phases. Because substantial crystallization occurs before magnetite appears in the boninite magma series, significant Fe enrichment, as depicted on an AFM diagram (Figure 5), occurs. This trend falls near the tholeiite - calc-alkaline rock series boundary of Irvine and Baragar (1971).

Dacite and quartz rhyolite lavas are the most differentiated members of the boninite magma suite. Almost all of the rhyolite lavas have undergone extensive chemical modification following devitrification and hydration, although one sample (MD-119) appears to retain near primary values. The chemical trends of these lavas (excluding the rhyolites affected by alteration) are consistent with predicted differentiation paths. Normalized ( $100 \%$ anhydrous) concentrations of silica $(66.0 \rightarrow 76.8), \mathrm{K}_{2} \mathrm{O}(0.8 \rightarrow 1.8)$, and $\mathrm{Na}_{2} \mathrm{O}(2.8 \rightarrow 3.3)$ all increase, while $\mathrm{TiO}_{2}(0.26 \rightarrow 0.15), \mathrm{Al}_{2} \mathrm{O}_{3}(13.9 \rightarrow 11.6)$, $\mathrm{Fe}_{2} \mathrm{O}_{3} *$ (7.9 $\left.\rightarrow 3.0\right), \mathrm{MnO}(0.11 \rightarrow 0.05), \mathrm{MgO}(2.0 \rightarrow 0.4), \mathrm{CaO}(6.2 \rightarrow 2.9)$ all decrease sharply with differentiation.

Calculated CIPW norm compositions for all boninite series lavas (with the sole exception of MD-71, a sample with abundant (cumulate?) olivine) are quartz normative. With differentiation, boninite series lavas increase in normative quartz, albite, and orthoclase contents, although normative Or never exceeds 10 mole percent. There is a quite substantial variation in diopside content for boninite and bronzite andesite lavas, mirroring the observed $\mathrm{CaO}$ variation, but Di concentrations drop consistently for more evolved lavas. Normative hypersthene declines rapidly in the more differentiated rocks. Magnetite, ilmenite, and apatite are only present as minor components in these normative calculations.

\section{Trace element variation}

Analyses of $\mathrm{Cr}, \mathrm{Ni}, \mathrm{V}, \mathrm{Rb}, \mathrm{Sr}, \mathrm{Ba}, \mathrm{Zr}$, and $\mathrm{Y}$ for whole-rock samples are given in Table 1, and these data are plotted against $\mathrm{Mg}$ number in Figure 6. Boninite lavas have high $\mathrm{Ni}(>200 \mathrm{ppm})$ and $\mathrm{Cr}(>500 \mathrm{ppm})$ contents characteristic of magmas in equilibrium with a mantle mineral assemblage (e.g., Sato, 1977), but the concentrations of these elements decrease rapidly with differentiation. $\mathrm{Sr}(75 \rightarrow 100 \mathrm{ppm})$ and $\mathrm{V}(150 \rightarrow 190 \mathrm{ppm})$ contents increase from boninite to bronzite andesite compositions, but the concentrations of these elements in more silicic lavas decrease with differentiation $(130 \rightarrow 90 \mathrm{ppm}$ for $\mathrm{Sr}, 170 \rightarrow 20$ for $\mathrm{V})$. $\mathrm{Rb}(10 \rightarrow 30), \mathrm{Ba}(25 \rightarrow 90), \mathrm{Zr}(30 \rightarrow 60)$, and $\mathrm{Y}(8 \rightarrow 27)$ all increase with decreasing $\mathrm{Mg}$ number.

The variation observed in these trends is in part attributable to alteration and analytical error. $\mathrm{Rb}, \mathrm{Sr}$, and $\mathrm{Ba}$ are fairly mobile elements, and their concentrations can undergo substantial modification with small degrees of alteration. A more serious problem is that of analytical resolution. All of the boninite series lavas contain very low concentrations of 
incompatible elements, and thus analyzed values are the near the limits of detection for XRF analysis and fall outside the range of most well-documented standards used for calibration. Errors associated with the lowest concentrations measured can exceed 20 percent.

The decrease in $\mathrm{Cr}$ and $\mathrm{Ni}$ contents can be attributed to the early fractionation of olivine, pyroxene, and chromium spinel. The initiation of significant plagioclase and magnetite crystallization around $\mathrm{Mg}$ \# 45-35 is marked by inflections in the $\mathrm{Sr}$ and $\mathrm{V}$ trends, with a decreased amount of these elements present in more silicic lavas. $\mathrm{Rb}, \mathrm{Ba}, \mathrm{Zr}$, and $\mathrm{Y}$ behave incompatibly throughout the differentiation sequence, increasing two to three times in concentration from boninite to rhyolite.

\section{Mineral Chemistry}

\section{Olivine}

Because of its rare occurrence and susceptibility to alteration, olivine was only analyzed in two boninite samples (Table 3). MD-71 is an altered boninite dike in which relict olivine cores are present within euhedral olivine pseudomorphs. These olivines are unzoned, ranging in composition from $\mathrm{Fo}_{89.5-91.9}$. NiO contents of these highly magnesium olivines are 0.25 to 0.32 wt. \%. Fresh olivine crystals were also analyzed from a boninite clast in a breccia horizon (MS-53). These olivine crystals are also unzoned, and have uniform compositions of $\mathrm{Fo}_{90.4-90.8}$.

Spinel

Reddish-brown chromium spinel is present in boninite and bronzite andesite as included phases in olivine, orthopyroxene, and clinoenstatite as well as in the groundmass. Representative analyses are presented in Table 4 . These spinels have very high $\mathrm{Cr}_{2} \mathrm{O}_{3}$ contents (49-63 wt. \%), and chromium numbers $(\mathrm{Cr} \#=\{100 \mathrm{Cr} /(\mathrm{Cr}+\mathrm{Al})\}$ molar $)$ ranging from 75 to 88 , magnesium numbers $\left(\mathrm{Mg} \#=\left\{100 \mathrm{Mg} /\left(\mathrm{Mg}+\mathrm{Fe}^{2+}\right)\right\}\right.$ molar) from 27 to 62 , and iron numbers $(\mathrm{Fe} \#=\{100$ $\left.\mathrm{Fe}^{3+} /\left(\mathrm{Fe}^{3+}+\mathrm{Cr}+\mathrm{Al}\right)\right\}$ molar $)$ from 2 to 12 . These spinels have similar compositions to those found in some alpine peridotite bodies (Dick and Bullen, 1984). Spinel crystals included within olivine and pyroxene crystals have higher $\mathrm{Mg}$ numbers than those in the groundmass within a given sample, and zonations measured within large spinel crystals indicate a decrease in $\mathrm{Mg}$ \# from core to rim, consistent with normal differentiation trends. Included spinels often have lower $\mathrm{Cr}$ numbers and higher Fe numbers than those found in the groundmass, in contrast to the decreases in $\mathrm{Cr} \#$ and increases in Fe \# observed from core to rim.

\section{Low-Ca pyroxene}

Three types of low-Ca pyroxene are present in the boninite magma series volcanic rocks, clinoenstatite, orthopyroxene, and pigeonite (Figure 7). Clinoenstatite occurs in boninite and bronzite andesite lavas, and is thought to be the inverted form of protoenstatite (Dallwitz et al., 1966). Clinoenstatite phenocrysts are unzoned and commonly are rimmed with orthopyroxene. These high-temperature, low-Ca phenocrysts range in composition from 0.23-0.38 wt. \% $\mathrm{CaO}$ and $0.10-$ 0.31 wt. $\% \mathrm{Cr}_{2} \mathrm{O}_{3}$ (Table 5). Recalculated quadrilateral components (Lindsley and Anderson, 1983) vary between $\mathrm{Wo}_{0.4-0.7}, \mathrm{En}_{89-91.5}$, and $\mathrm{Fs}_{8-10.5}$.

A wide range in orthopyroxene compositions is observed in the boninite magma suite. Orthopyroxenes in boninite lavas are usually bronzites, and have $\mathrm{X}_{\mathrm{Mg}}(\mathrm{En} /\{\mathrm{En}+\mathrm{Fs}\})$ compositions of 85 to 89 , although some phenocrysts are as iron-rich as $\mathrm{X}_{\mathrm{Mg}} 76$. Little zoning is found in most phenocrysts. Orthopyroxene rims on clinoenstatite and clinopyroxene crystals and groundmass microphenocrysts are typically more iron-rich, having $\mathrm{X}_{\mathrm{Mg}}$ values of 79-84. Orthopyroxenes of bronzite andesites have a similar compositional range. Most phenocrysts range from $\mathrm{X}_{\mathrm{Mg} \text { 80-90 }}$, but some phenocryst rims and microphenocrysts have $\mathrm{X}_{\mathrm{Mg}}$ compositions of 73-78. Orthopyroxenes from boninite and bronzite andesite lavas have low $\mathrm{Al}_{2} \mathrm{O}_{3}\left(<1.5\right.$, and mostly 1.0-0.3 wt. \%) and $\mathrm{TiO}_{2}(0.00-0.06$ wt. \%) contents, and have over $95 \%$ quadrilateral $(\mathrm{CaFeMg})$ components. These pyroxenes characteristically contain $0.2-0.4$ wt. $\% \mathrm{Cr}_{2} \mathrm{O}_{3}$.

Rare pigeonite occurs as a groundmass phase in some boninite and bronzite andesite lavas. Analyzed microphenocrysts in boninite and bronzite andesite have $\mathrm{X}_{\mathrm{Mg}}$ numbers of 81 and 74, respectively (Table 5).

Compositional variation between different $\mathrm{Ca}$-poor pyroxenes has been studied experimentally in the system $\mathrm{CaO}$ $\mathrm{MgO}-\mathrm{Al}_{2} \mathrm{O}_{3}-\mathrm{SiO}_{2}$ (Biggar, 1985). Distinct compositional gaps were observed for the CMAS system between the 
different low-Ca pyroxenes with regards to $\mathrm{CaO}$. The $\mathrm{CaO}$ contents of protopyroxene (clinoenstatite) range from 0.0 to 1.0 wt. $\% \mathrm{CaO}$, orthopyroxene from 1.4 to $2.2 \mathrm{wt}$. \%, and pigeonite from 3.0 to $6.5 \mathrm{wt}$. \%. However, for boninite and bronzite andesite lavas containing both clinoenstatite and orthopyroxene, observed compositional differences between these two phases are much smaller, with only a small gap (0.38-0.55 wt. \%) in $\mathrm{CaO}$ present. Similar compositional gaps in $\mathrm{CaO}$ content between clinoenstatite and bronzite of 0.3-0.65 (Dallwitz et al., 1966) and 0.36-0.70 wt. \% (Nakamura, 1971) were found for high magnesian andesite from Cape Vogel, Papua. Komatsu (1980) and Shiraki et al. (1980) reported a slight shift to higher values (0.49-0.80 and 0.67-0.95 wt. \% $\mathrm{CaO}$, respectively) for the Ca compositional gap in low-Ca pyroxenes analyzed in boninite samples obtained from their type locality. The difference in experimental and natural pyroxene compositions may be a reflection of the compositional differences and distinct crystallization histories between the experimental and natural systems. Late-stage, Fe-rich $\left(\mathrm{X}_{\mathrm{Mg}}<80\right)$ bronzite found rimming clinoenstatite in boninite and bronzite andesite samples contains over $1.9 \mathrm{wt} . \% \mathrm{CaO}$, and may better correspond with the compositional gap seen in Biggar's experimental study. A general trend towards increased $\mathrm{Al}_{2} \mathrm{O}_{3}$ contents with increasing $\mathrm{CaO}$ is seen in these low-Ca pyroxenes. This increase is probably a result of crystallization in these plagioclase-poor or free compositions, causing an increase in alumina content in the cooler residual liquid.

Both orthopyroxene and pigeonite are present in more silicic lavas. Orthopyroxene phenocrysts of most dacite lavas fall

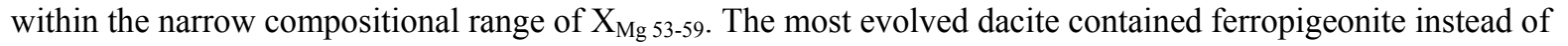
orthopyroxene, with $X_{\mathrm{Mg}}$ numbers ranging from 43 to 28 . All of these pyroxenes contain greater than $95 \%$ quadrilateral components.

Quartz dacite lavas contain two distinct orthopyroxene populations found in all thin sections examined. One group of pyroxenes consists of relatively unzoned phenocrysts ranging from $\mathrm{X}_{\mathrm{Mg} 58-68}$. The second, more abundant pyroxene population, ranges in $X_{\mathrm{Mg}}$ numbers from 46 to 52 . These phenocrysts occasionally have resorbed margins with optically distinct Mg-rich outer rims. Microphenocrysts have $\mathrm{X}_{\mathrm{Mg}}$ numbers of about 60 (Table 5; Figure 7).

Quartz-bearing rhyolites also contain orthopyroxene phenocrysts. Analyzed phenocrysts are unzoned and have a

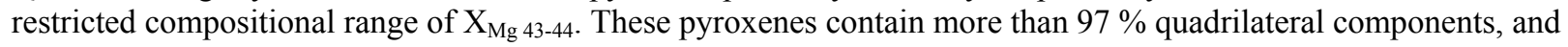
have quite high $\mathrm{MnO}$ contents of around $1 \%$.

\section{High-Ca pyroxene}

Ca-rich clinopyroxene occurs in all volcanic rock types of the boninite suite (Table 6; Figure 7). Augite phenocrysts in boninite lavas range in composition from $\mathrm{Wo}_{32.4} \mathrm{En}_{53.5} \mathrm{Fs}_{14.1}$ to $\mathrm{Wo}_{43.6} \mathrm{En}_{42.0} \mathrm{Fs}_{14.4}$. A smaller range in augite compositions was observed in bronzite andesite lavas $\left(\mathrm{Wo}_{40.8} \mathrm{En}_{46.3} \mathrm{Fs}_{12.9}\right.$ to $\left.\mathrm{Wo}_{40.3} \mathrm{En}_{43.5} \mathrm{Fs}_{16.2}\right)$. Ca-rich pyroxenes in dacitic lavas span a compositional range from augite $\left(\mathrm{Wo}_{40.0} \mathrm{En}_{37.0} \mathrm{Fs}_{23.1}\right.$ to $\mathrm{Wo}_{38.9} \mathrm{En}_{33.4} \mathrm{Fs}_{27.7}$ in most samples) to ferroaugite $\left(\mathrm{Wo}_{39.4} \mathrm{En}_{31.3} \mathrm{Fs}_{29.2}\right.$ to $\mathrm{Wo}_{37.7} \mathrm{En}_{26.7} \mathrm{Fs}_{35.5}$ in the most differentiated sample analyzed).

As in the case with orthopyroxene, quartz dacite lavas contain augite phenocrysts with substantial compositional differences. Numerous clinopyroxene phenocrysts have $\mathrm{X}_{\mathrm{Mg}}$ values between 54 and 61 (typical composition of $\left.\mathrm{Wo}_{42} \mathrm{En}_{35} \mathrm{Fs}_{23}\right)$, but some phenocrysts and all analyzed microlites have much more Mg-rich compositions $\left(\mathrm{X}_{\mathrm{Mg} \text { 67-75) }}\right.$. These phenocrysts range in composition from $\mathrm{Wo}_{39.0} \mathrm{En}_{45.8} \mathrm{Fs}_{15.3}$ to $\mathrm{Wo}_{44.6} \mathrm{En}_{38.6} \mathrm{Fs}_{16.8}$.

Augite phenocrysts in quartz rhyolite lavas have rather restricted compositions. These crystals have $\mathrm{X}_{\mathrm{Mg}}$ values between 58-62 and range from $\mathrm{Wo}_{41.9} \mathrm{En}_{36.2} \mathrm{Fs}_{21.9}$ to $\mathrm{Wo}_{43.0} \mathrm{En}_{33.0} \mathrm{Fs}_{24.1}$ in quadrilateral components.

Ca-rich clinopyroxene compositions throughout the boninite lava suite contain low $\mathrm{Na}_{2} \mathrm{O}\left(<0.25\right.$ wt. \%) and $\mathrm{TiO}_{2}$ $\left(<0.20\right.$ wt. \%), and commonly have less than 2 wt. $\% \mathrm{Al}_{2} \mathrm{O}_{3}$, but some phenocrysts and microlites contain greater than 3 wt. \% alumina. This increase in $\mathrm{Al}_{2} \mathrm{O}_{3}$ content is not due to increasing pressure, but is a compositional effect. Because no Al-bearing phases are present in boninite lavas, residual glasses in more crystal-rich samples (e.g. MS-53, Table 2) have high alumina contents, and late stage clinopyroxene have accordingly high $\mathrm{Al}_{2} \mathrm{O}_{3}$ contents. Clinopyroxene phenocrysts in boninite and bronzite andesite lavas contain significant amounts of chromium (commonly more than 0.25 wt. \%, and up to 0.5 wt. $\% \mathrm{Cr}_{2} \mathrm{O}_{3}$ ).

\section{Feldspar}


Plagioclase feldspar is present in all bronzite andesite, dacite, quartz dacite, and rhyolite volcanic rocks. Analyzed feldspar phenocrysts in bronzite andesite lavas have little zoning, and range in composition from $\mathrm{An}_{70}$ to $\mathrm{An}_{87}(\mathrm{Table}$ 7). Plagioclase phenocrysts in dacites span a larger compositional range, from $\mathrm{An}_{83}$ in more mafic samples to $\mathrm{An}_{58}$ in the most evolved dacite analyzed.

Quartz dacite lavas contain plagioclase phenocrysts with very distinct chemical zonations. Analyzed core compositions range from $\mathrm{An}_{45}$ to $\mathrm{An}_{70}$. These crystals often have fairly homogenous interior compositions, but many phenocrysts have sharp chemical zonation reversals at the outer rim, with these rims having compositions of $\mathrm{An}_{74-78}$ (Figure 8a).

The most sodic plagioclase of the boninite volcanic suite occurs in rhyolitic lavas, with an An content of 42. In some phenocrysts, cores of $\mathrm{An}_{70}$ have sharp optical and compositional breaks, with rims of $\mathrm{An}_{50}$ (Figure $8 \mathrm{~b}$ ). Other large plagioclase crystals have distinct optical zoning, but exhibit rather little chemical variation $\left(\mathrm{An}_{43-53}\right)$.

All plagioclase have low $\mathrm{K}_{2} \mathrm{O}$ and $\mathrm{TiO}_{2}$ contents. $\mathrm{K}_{2} \mathrm{O}$ contents of analyzed feldspars increase with increasing $\mathrm{Ab}$ content, from $0.02 \mathrm{wt} \% \mathrm{~K}_{2} \mathrm{O}$ for $\mathrm{An}_{85}$ to 0.09 wt. \% for phenocrysts with $\mathrm{An}_{60}$. Groundmass plagioclase feldspars in silicic samples have slightly higher potash contents, but $\mathrm{K}$ resides principally within the glass. $\mathrm{TiO}_{2}$ is very low $(<0.05$ wt. \%) for all feldspars analyzed. Iron contents of feldspars decrease with decreasing An number (1.1-0.4 wt. \% FeO).

\section{Magnetite}

Magnetite is present as the only Fe- Ti oxide phase in dacite, quartz dacite, and rhyolite samples. All analyzed oxide grains were fairly homogeneous. Quartz dacite samples contain magnetite ranging in composition (after calculation of $\mathrm{Fe}^{3+}$ ) from $\mathrm{Mt}_{76} \mathrm{Ul}_{24}$ to $\mathrm{Mt}_{87} \mathrm{Ul}_{13}$. Magnetite in rhyolitic lavas varies in composition between $\mathrm{Mt}_{71-75}$, and groundmass $\mathrm{Fe}-\mathrm{Ti}$ oxides from the most evolved dacite have a compositional range of $\mathrm{Mt}_{64-75}$. All analyzed magnetite have $\mathrm{MgO}$ contents lower than 2.1 wt. \%, $\mathrm{MnO}$ less than 0.3 wt. \%, and $\mathrm{Al}_{2} \mathrm{O}_{3}<2.8$ wt. \% (Table 8).

\section{Temperature and oxygen fugacity estimates for boninite series lavas}

A variety of geothermometers were used to estimate eruption temperatures of boninite series lavas. Temperatures calculated using olivine-spinel geothermometers are widely variable, and are not reliable. However, several pyroxene geothermometers give internally consistent (usually within $30^{\circ} \mathrm{C}$ ) and reliable temperatures. Orthopyroxeneclinopyroxene geothermometry of Wells (1977) and Lindsley (1983) using the equations of Lindsley and Anderson (1983), high-Ca pyroxene geothermometry of Kretz (1982), and the pigeonite eutectoid reaction of Ishii (1980) were used to calculate temperatures (Table 9). Boninite lavas range in temperature from $1260^{\circ} \mathrm{C}$ (MD-94) to $1100^{\circ} \mathrm{C}$ (MD52). These values are similar to the range of pigeonite temperatures $\left(1150-1215^{\circ} \mathrm{C}\right)$ reported by Umino (1986) for boninite samples from Chichi-jima. Estimated temperatures for bronzite andesite lavas overlap those of boninite magmas but are generally lower, ranging from 1050 to $1150^{\circ} \mathrm{C}$. Calculated temperatures from pyroxene pairs in dacite lavas are around $1000^{\circ} \mathrm{C}$.

Quartz dacite lavas contain a disequilibrium pyroxene assemblage, and thus it is difficult to estimate eruption temperatures for these magmas. Orthopyroxene compositions fall into two very distinct populations, but it is more difficult to break down the clinopyroxene division. The Kretz (1982) clinopyroxene geothermometer yields temperatures ranging from 795 to $1188^{\circ} \mathrm{C}$ for augite from D-39, and a similar wide range in temperatures was calculated for MD-65 $\left(835\right.$ to $\left.1135^{\circ} \mathrm{C}\right)$. This extreme range in temperature may reflect different crystallization histories for the different pyroxene populations prior to mixing (discussed later). Temperature estimates for rhyolitic lavas determined with the different geothermometers are quite different, varying from values of 850 to $861^{\circ} \mathrm{C}$ calculated using the equations of Lindsley and Anderson (1983) and Kretz (1982) to a temperature of $966^{\circ} \mathrm{C}$ obtained with the Wells (1977) geothermometer using the same pyroxene pair.

Because only one Fe- Ti oxide is present in the boninite magma suite (magnetite), it is difficult to determine oxygen fugacities of these lavas. However, for the rhyolitic lavas, the assemblage orthopyroxene-magnetite-quartz is present. The equation $\log \mathrm{fO}_{2}=\log \mathrm{K}-6 \log \left(\text { activity } \mathrm{FeSiO}_{3}\right)_{\text {opx }}+6 \log \left(\right.$ activity $\left.\mathrm{SiO}_{2}\right)$ qtz $+2 \log \left(\text { activity } \mathrm{Fe}_{3} \mathrm{O}_{4}\right)_{\mathrm{Fe}-\mathrm{Ti} \text { oxide }}$ can be used for estimating oxygen activities. The equilibrium coefficient for this reaction can be determined using the SUPCRT database (Helgeson et al., 1978), and at $865^{\circ} \mathrm{C}$ (average of $17 \mathrm{Kretz}$ (1982) clinopyroxene temperatures) and 0.5-1.0 kbar, the $\log \mathrm{K}$ value is -14.1. For MD-119, using the activities, calculated assuming ideal mixing, of $\mathrm{a}_{\mathrm{mt}}=$ 0.7446 (average of 11 analyses), $\mathrm{a}_{\mathrm{fs}}=0.528$ (average of 7 analyses), and $\mathrm{a}_{\mathrm{qtz}}=1.0$, a $\log \mathrm{fO}_{2}$ value of -12.69 is obtained. 
This value lies between the QFM and HM buffers and is very near those of orthopyroxene rhyolites from Mono Craters and Medicine Lake in California (Carmichael, 1967).

\section{Boninite as a primary mantle melt}

Numerous petrologic and experimental studies have focused on the origin of orogenic andesite lavas (e.g. Green, 1973a; Boettcher, 1973; Perfit et al., 1980; Arculus and Johnson, 1981; Gill, 1981; Kay, 1984). It is now generally accepted that most andesites are not primary mantle melts, but are instead derivatives of basaltic magmas. Kuroda et al. (1978) proposed that boninites were primary melts that formed under high $\mathrm{P}_{\mathrm{H} 2 \mathrm{O}}$ conditions. A number of experimental studies (e.g., Kushiro, 1972, 1974; Green, 1973b, 1976; Tatsumi, 1981; Umino and Kushiro, 1989; van der Laan et al., 1989) indicate that it is possible to derive silicic boninite-like magmas from mantle material with fairly high degrees of partial melting under water-saturated conditions and at pressures less than $15 \mathrm{kbar}$.

Numerous geochemical characteristics of boninite suggest that their parent magmas were in equilibrium with mantle material and thus represent partial melting of the mantle. Boninites have high $\mathrm{NiO}$ contents $(>0.03 \mathrm{wt} . \%)$ and $\mathrm{Mg}$ numbers $(>70)$ that reflect the presence of clinoenstatite and Mg-rich bronzite and olivine; such features are consistent with the derivation of boninite magmas from the mantle (Green et al., 1974; Sato, 1977). Cr-rich spinels found in boninite magmas have compositional counterparts found only in alpine (Type III) peridotites. Dick and Bullen (1984) suggest that such spinels can only form in a magma derived from a highly depleted source where all diopside has been removed during the partial melting process.

The low concentrations of incompatible elements found in boninite series lavas also suggest that boninite magmas were derived from a depleted source. The low Ti contents of boninite magmas are unique, resulting in correspondingly low $\mathrm{TiO}_{2} / \mathrm{Al}_{2} \mathrm{O}_{3}$ and $\mathrm{TiO}_{2} / \mathrm{CaO}$ ratios compared to estimated mantle values (61-92 and 37-95 versus 20 and 17, respectively). Sun and Nesbitt (1978) interpret these low ratios to be due to refractory mantle material, with earlier melt extraction lowering these ratios in the source ( $\mathrm{Ti}$ is more incompatible than $\mathrm{Al}$ and $\mathrm{Ca}$ ). Experimental work (Green and Pearson, 1986) indicates that it is very unlikely that these low Ti contents are due to a residual Ti-bearing phase in the mantle.

The concentrations of other incompatible elements are extremely low in boninite lavas. High-field strength elements in boninites are present in only one-half to one-fifth the abundances observed in depleted MORB (Sun and McDonough, 1989). Trace element data from this study are too limited and imprecise to permit detailed analysis, but agree well with geochemical studies of boninite lavas from a variety of localities (Jenner, 1981; Hickey and Frey, 1982; Cameron et al., 1983; Karpenko et al., 1985; Cameron, 1985; Stern et al., 1991). The enrichment in large-ion lithophile elements such as $\mathrm{K}, \mathrm{Rb}, \mathrm{Ba}$, and $\mathrm{Sr}$ observed in boninites prompted these workers to suggest that boninite source areas have undergone metasomatic modification. This enrichment is similar to that observed in most island arc andesites (Kay, 1980; Arculus and Johnson, 1981; Gill, 1981). Strontium and neodymium isotopic analyses of boninite lavas from a variety of localities have a fairly wide range of values ( $\varepsilon$ Nd from -0.3 to $8.1,{ }^{87} \mathrm{Sr} /{ }^{86} \mathrm{Sr}$ from 0.7036 to 0.7064 ; Hickey and Frey, 1982; Cameron et al., 1983; Karpenko et al., 1985) Although some of the high ${ }^{87} \mathrm{Sr} /{ }^{86} \mathrm{Sr}$ values may be due to seawater contamination (Karpenko et al., 1985), there is still a large range in isotopic compositions, even within a single boninite locality. Hickey and Frey (1982) note a positive correlation between $\varepsilon N d$ and $\mathrm{Sm} / \mathrm{Nd}$ for each locality studied, and postulate that different amounts of a LREE-enriched fluid have been added, resulting in different amounts of isotopic and geochemical modification of these melts.

The fluids involved in the metasomatism of boninite source material are probably a key feature in boninite genesis, as they would lower liquidus temperatures for the melting of residual mantle. The introduction of water into an olivineorthopyroxene-rich mantle would allow incongruent melting of orthopyroxene to occur, thus producing a silica- and magnesium-rich melt. The water present in boninite melts is often preserved in erupted boninite lavas as a dissolved phase in glass (Dobson and O'Neil, 1987; Dobson et al. 1995), and in quench amphiboles in some boninite lavas (Cameron et al., 1979; Walker and Cameron, 1983; Sameshima et al., 1983), but were not observed in any of the samples examined in this study. The stable isotope composition of this fluid is distinct from water found in MORB glasses, and is probably derived from dehydration of subducting oceanic lithosphere (Dobson and O'Neil, 1987). This fluid also serves as the transport mechanism for large-ion lithophile elements that are derived from the downgoing slab and are incorporated in boninite magmas (e.g., Tatsumi et al., 1986; Stern et al., 1991). The chemical and isotopic signature of the boninite source region can be easily overprinted because of the low concentrations of incompatible 
elements. $\mathrm{Pb}$ isotopic data (Dobson and Tilton, 1989) suggest that a small crustal (sedimentary) component present in the Bonin Island boninites dominates the lead isotopic signature of these magmas.

Differentiation of the boninite magma suite

The crystallization sequence of boninite magmas has been extensively investigated experimentally. Howard and Stolper (1981) examined the crystallization sequences for two boninite samples from the Mariana Trench. For the most primitive sample, olivine and spinel began to crystallize at $1335^{\circ} \mathrm{C}$ (at $1 \mathrm{~atm}$ ) first, and with decreasing temperatures, these phases reacted with the melt to form orthopyroxene, which was the only crystallizing phase observed for a temperature range of over $100^{\circ} \mathrm{C}$. Similar crystallization sequences were reported by van der Laan et al. (1989) and Umino and Kushiro (1989) for one atmosphere experimental runs using boninite samples. Melting and crystallization experiments conducted by van der Laan et al. (1989) and Umino and Kushiro (1989) on boninite samples at higher (up to $20 \mathrm{kbar}$ ) pressures suggest that the primary boninite magmas had at least $3 \% \mathrm{H}_{2} \mathrm{O}$, consistent with measurements of dissolved water contents (2.8-3.2\%) of boninite glass inclusions (Dobson et al., 1995).

The trends of major element concentrations plotted against Mg number, as shown earlier, suggest that orthopyroxene is the primary phase during the early stages of crystallization, and that plagioclase becomes the dominant mineral in more differentiated lavas. Projections of normative compositions are used to evaluate the crystallization history of boninite series magmas, and least-squares modeling is used to evaluate crystal fractionation.

Ternary Projections for the System Plagioclase-Diopside-Olivine-Quartz

Numerous projection schemes have been formulated to permit comparison of analyzed samples that could represent magmatic compositions with experimentally determined phase relations. Ternary projections in the system plagioclasediopside-olivine-quartz are commonly used for magmas of basaltic composition. The projection scheme of Walker et al. (1979) is used to plot boninite and bronzite andesite compositions on plagioclase (Ol-Qz-Di) and diopside (Qz-OlPl) ternary projections. Molecular proportions are combined and then plotted using the following formulas:

Plagioclase $=\mathrm{Al}_{2} \mathrm{O}_{3}+\mathrm{Na}_{2} \mathrm{O}+\mathrm{K}_{2} \mathrm{O}$

Diopside $=\mathrm{CaO}-\mathrm{Al}_{2} \mathrm{O}_{3}+\mathrm{Na}_{2} \mathrm{O}+\mathrm{K}_{2} \mathrm{O}$

Olivine $=\left(\mathrm{FeO}+\mathrm{MgO}+\mathrm{MnO}+2 \mathrm{Fe}_{2} \mathrm{O}_{3}+\mathrm{Al}_{2} \mathrm{O}_{3}-\mathrm{CaO}-\mathrm{Na}_{2} \mathrm{O}-\mathrm{K}_{2} \mathrm{O}\right) / 2$

Silica $=\mathrm{SiO}_{2}-\left(\mathrm{Al}_{2} \mathrm{O}_{3}+\mathrm{FeO}+\mathrm{MgO}+\mathrm{MnO}+3 \mathrm{CaO}+11 \mathrm{Na}_{2} \mathrm{O}+11 \mathrm{~K}_{2} \mathrm{O}+2 \mathrm{Fe}_{2} \mathrm{O}_{3}\right) / 2$

Samples with Mg numbers $>80$ are not plotted because they are observed to have accumulated crystals. Lavas are plotted according to $\mathrm{Mg} \#$ on the projections shown in Figure 9. Although the phase diagrams are constructed using experimental data from basaltic compositions which are saturated in olivine, clinopyroxene, and plagioclase, thus differing significantly from boninite magmas, these diagrams provide useful comparative information with regards to the early crystallization history of these magmas.

In the ternary projection Ol-Qz-Di (Figure 9a), primary fields of olivine, clinopyroxene, orthopyroxene, and silica phases are shown at $1 \mathrm{~atm}$ pressure using the projected plagioclase-saturated liquidus of Walker et al. (1979).

Compositions of boninite and bronzite andesite lavas almost all fall within the low-Ca pyroxene field. Increasing pressure expands the orthopyroxene field (Stolper, 1980) at the expense of olivine and clinopyroxene, and thus does not modify this inference. Two separate trends are observed for the plotted lavas with differentiation, suggesting that more than one 'primary' magma composition may be present. One liquid trend moves along the opx-ol boundary until reaching the peritectic point involving clinopyroxene, where olivine is resorbed, and then the liquid composition moves along the opx-cpx cotectic line. The second starting composition lies within the orthopyroxene field, and its fractionation trend moves away from orthopyroxene until reaching the orthopyroxene-clinopyroxene cotectic line, where it follows a path similar to that of the first liquid.

In the second projection, Qz-Ol-Pl, plotted compositions (Figure 9b) fall within the olivine, orthopyroxene, and plagioclase fields for the $1 \mathrm{~atm}$ liquidus projection. Higher pressures affect this phase diagram dramatically, with the orthopyroxene field expanding dramatically at the expense of olivine and plagioclase (Stolper, 1980). Projected data for boninite and bronzite magmas plot in a linear trend moving away directly from orthopyroxene. The most differentiated lavas included in this figure should lie near the plagioclase-orthopyroxene cotectic line because they mark the first appearance of plagioclase as a phenocryst phase. This necessitates that the projected liquidus be shifted away from the 
olivine apex, resulting in the contraction of the plagioclase stability field. This shift may be due to the high water contents of boninite melts, which would serve to suppress plagioclase crystallization (e.g. Yoder and Tilley, 1962). Similar liquid line of descent paths for boninite magmas are predicted for both pseudoternary systems by Grove and Kinzler (1986).

\section{Crystal fractionation modeling}

Least-squares crystal fractionation modeling of the boninite series magma suite was calculated using major-element compositions of whole-rocks and included minerals and the computer model XLFRAC of Stormer and Nicholls (1978). Multistep modeling, from boninite to bronzite andesite to dacite to rhyolite, was done to account for both the differences in mineral phases crystallizing and their changes in compositions. No preferential weighting was assigned to either mineral analyses or to individual elements.

Because of the substantial variation in boninite lava compositions, several starting compositions were tested. MD-94 and MD-97 are the freshest boninite samples analyzed, and were first tested for fractionation of olivine, orthopyroxene, and clinopyroxene to obtain MD-114, a bronzite andesite. A large proportion of olivine relative to orthopyroxene is required for this model, but petrographic and experimental evidence suggest that olivine is not a major phase in boninite fractionation trends. By using MD-54 as a starting composition, the calculated least-squares crystallization data conform much better to the observed mineralogy, and thus this sample was selected as the starting composition for these calculations.

The results of the least-squares modeling are presented in Table 10. MD-114 was chosen as a representative bronzite andesite sample (marked by the first appearance of plagioclase as a phenocryst phase), MD-43 was used as an intermediate dacite composition, and MD-119 was selected as the end product of differentiation.

This three-step model requires that $31.27 \%$ of the starting composition crystallize in the amounts $22.41 \%$ opx, $4.40 \%$ cpx, and $4.46 \%$ ol to form a residual liquid with a composition similar to that of MD-114, a bronzite andesite. Crystallization of about half of the remaining liquid (10.39\% opx, $7.46 \% \mathrm{cpx}, 13.43 \% \mathrm{plag}$, and $2.08 \% \mathrm{mt}$, relative to the starting liquid) will produce MD- 43 , and with additional crystallization ( $1.63 \% \mathrm{opx}, 0.60 \% \mathrm{cpx}, 5.26 \% \mathrm{plag}$, and $0.98 \% \mathrm{mt}$ ), a final liquid ( $26.94 \%$ of the starting material) with a composition similar to MD-119 is produced. The sum of the squares of the residuals for these steps range from 0.08 to 0.20 .

With nearly 75 percent crystallization of the primary magma to produce rhyolitic lavas, observed concentrations of incompatible elements $\left(\mathrm{K}_{\text {Dmineral-melt }}<0.1\right)$ in rhyolitic rocks should be three to four times greater than those found in boninite lavas. Increases in $\mathrm{Rb}$ (8-12 ppm in boninites, 26-32 ppm in rhyolites), Ba (22-30 ppm in boninites, 88-92 ppm in rhyolites), $\mathrm{Zr}$ (29-33 ppm in boninites, 52-65 ppm in rhyolites), and Y (7-9 ppm in boninites, 16-29 ppm in rhyolites) are consistent with this predicted rise in the abundance of incompatible elements. Because the fractionation model agrees with observed changes in mineralogy as well as with the trace element data, it is likely that fractional crystallization plays a major role in the generation of differentiated lavas in the boninite magma suite studied here.

Previous workers (e.g., Bloomer and Hawkins, 1987; Meijer, 1983) have described the existence of a boninite magma series in the Mariana arc-trench area. In a study of boninite lavas recovered from the arc side of the Mariana Trench wall, Bloomer and Hawkins (1987) found intermediate volcanic rocks that they interpreted to be cogenetic with boninite samples. Meijer (1983) described low-K rhyolites thought to represent differentiated products of boninite volcanism that contain very low incompatible element concentrations. Neither of these studies was able to provide conclusive field evidence, such as seen on Chichi-jima, which documents the close relation between boninite and more evolved compositions (e.g., Kuroda and Shiraki, 1975; Kuroda et al., 1984; Umino, 1985).

These two studies use end member modeling to predict crystal fractionation trends (Table 11). Meijer (1983) derived the Saipan rhyolite, using boninite from DSDP hole 458 (60-458-43-2) as a starting composition, by removal of $22.0 \%$ opx, $13.6 \% \mathrm{cpx}, 39 \%$ plagioclase, and minor magnetite, ilmenite, and apatite, with a total of $77.7 \mathrm{wt} . \%$ crystals removed. Bloomer and Hawkins (1987) used two compositions spanning a smaller compositional difference, and calculated that just over $50 \%$ crystallization of an initial magma with $\mathrm{MgO}=15.3 \mathrm{wt}$. $\%$ was required $(13.54 \%$ ol, $21.98 \%$ opx, $5.43 \% \mathrm{cpx}$, and $9.72 \%$ plagioclase $)$ to obtain a close match to the most felsic 'cogenetic' lavas $\left(\mathrm{SiO}_{2}=\right.$ 67.5 wt. \%) studied. 
The model presented here is fairly similar to these other differentiation schemes, considering the differences in end member magma compositions examined. A smaller amount of olivine is required in this model compared to that of Bloomer and Hawkins, but as noted earlier, the relative abundances of orthopyroxene and olivine is strongly controlled by the starting composition selected. The final composition in the Bloomer and Hawkins model is much less fractionated than the rhyolites used in the other models, but is fairly near the dacitic composition (MD-43) of this model. Comparison of the Bloomer and Hawkins model with fractionation to dacitic compositions yields similar relative abundances of crystallizing phases, with olivine showing the only difference (opx $>$ ol $>$ plag $>$ cpx versus $\mathrm{opx}>$ plag $>\mathrm{cpx}>\mathrm{ol}$ ). Meijer's model does not include olivine as a fractionating phase because an olivine-free starting composition was chosen. The selection of a less $\mathrm{MgO}$-rich end member $(\mathrm{MgO}=6.4 \mathrm{wt} . \%)$ and the altered nature of the rhyolitic end product $\left(81.4\right.$ wt. \% $\mathrm{SiO}_{2}$ ) in Meijer's model are most likely responsible for the disparity in estimated amounts of feldspar fractionation.

Magma mixing in quartz-bearing dacitic lavas

Textural features observed in quartz dacite lavas (Figure 3) suggest that these magmas have disequilibrium mineral assemblages resulting from magma mixing (Kuroda et al., 1984). Microprobe analyses of pyroxene and feldspar phenocrysts indicate that two geochemically distinct crystal populations were present in these magmas when they crystallized. Quartz phenocrysts, Fe-rich pyroxene, and plagioclase $\left(\mathrm{An}_{50}\right)$ probably were derived from a rhyolitic melt, and were mixed with a bronzite andesite magma, resulting in sharp zoning reversals and resorption features.

Examination of quartz stability for the system anorthite-albite-quartz illustrates that quartz is highly unstable in quartz dacite lavas and thus quartz could not have crystallized from a melt of this composition even after substantial crystallization. Cotectic curves for plagioclase-quartz at 1, 2, 4, and $5 \mathrm{kbar}$ obtained from Tuttle and Bowen (1958), Stewart (1967), Yoder (1968), and Hoffmann (1976) are shown in Figure 10 together with normative projections of quartz-bearing lavas. Quartz dacite compositions of both whole rocks and residual glass lie outside of the quartz stability field, in contrast to the plotted projections for rhyolitic lavas. The resorption rims seen on quartz phenocrysts in these rhyolitic lavas are probably generated during decompression of the rhyolitic magmas during ascent to the surface upon eruption.

Summary of petrologic and geochemical observations

Boninite, bronzite andesite, dacite, quartz dacite and rhyolite volcanic rocks that crop out on the island of Chichi-jima comprise an Eocene boninite magma series. Boninites from the Bonin Islands are characterized mineralogically by the absence of plagioclase and abundance of orthopyroxene set in a high-silica, water-rich glassy matrix. However, these rocks are more readily identified by their unique geochemical signature. $\mathrm{High} \mathrm{MgO}, \mathrm{Cr}$, and $\mathrm{Ni}$ contents indicate that these magmas equilibrated with mantle material, but unlike other primary mantle melts, boninite lavas are water and silica-rich. All boninite series lavas contain unusually low incompatible element concentrations, which reflect derivation from a depleted harzburgite mantle source.

Major and trace-element analyses of boninite series lavas suggest that these lavas are indeed cogenetic. Consistent trends in elemental concentrations related to $\mathrm{Mg}$ number support differentiation, and changes in these fractionation paths correspond well with the appearances of new crystallizing phases. Boninite series lavas span a temperature range of $1250-850^{\circ} \mathrm{C}$. The absence of magmatic hydrous phases in silicic lavas suggests that boninite magmas degassed prior to differentiation, or that fractionation took place at pressures less than $2 \mathrm{kbar}$, where the crystallization of amphibole and biotite would not occur (e.g., Holloway and Burnham, 1972).

Least-squares modeling of observed boninite series lava and mineral compositions indicates that fractional crystallization of olivine, orthopyroxene, clinopyroxene, plagioclase, and magnetite can produce the observed magma sequence. Strong evidence for mixing of fractionated components within the boninite magma suite is present within the quartz dacite lavas. Significant compositional variation observed in boninite magmas may be due to differing degrees of magmatic crystal accumulation and post-magmatic alteration, but probably also reflects some real differences in mantle partial melting with variable subducted slab fluid compositions.

Experimental work by Kushiro (1972; 1974) and Green (1973b; 1976) constrain boninite genesis to depths shallower than $50 \mathrm{~km}$. A generally accepted scenario for boninite magma genesis (e.g. Shiraki et al., 1978; Sun and Nesbitt, 1978; 
Hickey and Frey, 1982) is that boninite lavas are derived from depleted mantle material from the mantle wedge above subduction zones. Upwards moving fluids from dehydrating downgoing oceanic lithosphere promote melting of this refractory material where sufficient heat is available and enrich the source in large-ion lithophile elements. These unique magmas pond in high-level magma chambers, where they undergo low-pressure fractionation to produce more evolved members of the boninite magma suite, such as bronzite andesites, dacites, and rhyolites. The generation of boninite melts is probably restricted to early stages of subduction, when the thermal regime of the mantle wedge has not yet been disrupted by the subduction of cool oceanic lithosphere. Boninite magmas share numerous characteristics with island arc tholeiites, such as high water contents, low incompatible element concentrations, and large-ion lithophile element enrichment (Jakeš and Gill, 1970). Boninites are often intimately associated with these lavas, and these two magma types may span a compositional spectrum, with boninite representing an early stage end member of this subduction-related volcanic rock series.

\section{Acknowledgements}

We wish to thank the officials of Ogasawara National Park, Japan, for their permission to collect the samples for this study. Financial support for this study was provided in part by the National Science Foundation (Grant EAR 84-18123 to J.G. Liou), the Geological Society of America (Harold T. Stearns Fellowship to P.F. Dobson), and the Stanford University Shell and McGee Funds.

\section{REFERENCES}

Arculus, R.J., and Johnson, R.W., 1981, Island-arc magma sources: a geochemical assessment of the roles of slabderived components and crustal contamination: Geochemical Journal, v. 15, p. 109-133.

Biggar, G.M., 1985, Calcium-poor pyroxenes: phase relations in the system $\mathrm{CaO}-\mathrm{MgO}-\mathrm{Al}_{2} \mathrm{O}_{3}-\mathrm{SiO}_{2}$ : Mineralogical Magazine, v. 49, p. 49-58.

Bloomer, S., and Hawkins, J.W., 1987, Petrology and geochemistry of boninite series volcanic rocks from the Mariana Trench: Contributions to Mineralogy and Petrology, v. 97, p. 361-377.

Boettcher, A.L., 1973, Volcanism and orogenic belts- the origin of andesites: Tectonophysics, v. 17, p. 223-240.

Cameron, W.E., 1985, Petrology and origin of primitive lavas from the Troodos ophiolite, Cyprus: Contributions to Mineralogy and Petrology, v. 89, p. 239-255.

Cameron, W .E., McCulloch, M. T., and Walker, D .A., 1983, Boninite petrogenesis: chemical and Nd-Sr isotopic constraints: Earth and Planetary Science Letters, v. 65, p. 75-89.

Cameron, W.E., Nisbet, E.G., and Dietrich, V.J., 1979, Boninites, komatiites and ophiolitic basalts: Nature, v. 280, p. $550-553$.

Carmichael, I.S.E., 1967, The iron-titanium oxides of salic volcanic rocks and their associated ferromagnesian silicates: Contributions to Mineralogy and Petrology, v. 14, p. 36-64.

Dallwitz, W.B., Green, D.H., and Thompson, J.E., 1966, Clinoenstatite in a volcanic rock from the Cape Vogel area, Papua: Journal of Petrology, v. 7, p. 375-403.

Dick, H.J.B., and Bullen, T., 1984, Chromian spinel as a petrogenetic indicator in abyssal and alpine-type peridotites and spatially associated lavas: Contributions to Mineralogy and Petrology, v. 86, p. 54-76.

Dobson, P.F., and O'Neil, J.R., 1987, Stable isotope compositions and water contents of boninitic series volcanic rocks from Chichi-jima, Bonin Islands, Japan: Earth and Planetary Science Letters, v. 82, p. 75-86.

Dobson, P.F., Skogby, H., and Rossman, G.R., 1995, Water in boninite glass and coexisting orthopyroxene: concentration and partitioning: Contributions to Mineralogy and Petrology, v. 118, p. 414-419. 
Dobson, P.F., and Tilton, G.R., 1989, Th, U and Pb systematics of boninite series volcanic rocks from Chichi-jima, Bonin Islands, Japan, in Crawford, A. J., ed., Boninites: London, UK, Unwin Hyman, p. 396-415.

Gill, J., 1981, Orogenic Andesites and Plate Tectonics: New York, Springer-Verlag, 390 p.

Green, D.H., 1973a, Contrasted melting relations in a pyrolite upper mantle under mid-oceanic ridge, stable crust and island arc environments: Tectonophysics, v. 17, p. 285-297.

Green, D.H., 1973b, Experimental melting studies on a model upper mantle composition under water-saturated and water-undersaturated conditions: Earth and Planetary Science Letters, v. 19, p. 37-53.

Green, D.H., 1976, Experimental testing of "equilibrium" partial melting of peridotite under water-saturated, highpressure conditions: Canadian Mineralogist, v. 14, p. 255-268.

Green, D. H., Edgar, A. D., Beasley, P., Kiss, E. and Ware, N. G. 1974, Upper mantle source for some hawaiites, mugearites and benmoreites: Contributions to Mineralogy and Petrology, v. 48, p. 33-43.

Green, T.H., and Pearson, N.J., 1986, Ti-rich accessory phase saturation in hydrous mafic-felsic compositions at high P, T: Chemical Geology, v. 54, p. 185-201.

Grove, T.L., and Kinzler, R.J., 1986, Petrogenesis of andesites: Annual Review of Earth and Planetary Sciences, v. 14, p. 417-454.

Helgeson, H.C., Delany, J.M., Nesbitt, H.W., and Bird, D.K., 1978, Summary and critique of the thermodynamic properties of rock-forming minerals: American Journal of Science, v. 278A, p. 1-229.

Hickey, R.L., and Frey, F.A., 1982, Geochemical characteristics of boninite series volcanics: implications for their source: Geochimica et Cosmochimica Acta, v. 46, p. 2099-2115.

Hoffmann, C., 1976, Natural granitic rocks and granite systems Qz-Or-Ab-An- $\left(\mathrm{H}_{2} \mathrm{O}\right)$ and Qz-Ab-An- $\left(\mathrm{H}_{2} \mathrm{O}\right)$ : Neues Jahrbuch für Mineralogie - Monatshefte, p. 289-306.

Holloway, J.R., and Burnham, C.W., 1972, Melting relations of basalt with equilibrium water pressure less than total pressure: Journal of Petrology, v. 13, p. 1-29.

Howard, A.H., and Stolper, E., 1981, Experimental crystallization of boninite from the Mariana Trench: Eos, v. 62, p. 1091.

Irvine, T .N., and Baragar, W.R.A., 1971, A guide to the chemical classification of the common volcanic rocks: Canadian Journal of Earth Sciences, v. 8, p. 523-548.

Ishii, T., 1980, Pyroxene geothermometry of basalts and an andesite from the Palau-Kyushu and West Mariana Ridges, Deep Sea Drilling Project: Initial Reports of the Deep Sea Drilling Project, v. 59, p. 693-718.

Jakeš, P., and Gill, J.B., 1970, Rare earth elements and the island arc tholeiite series: Earth and Planetary Science Letters, v. 9, p. 17-28.

Jenner, G.A., 1981, Geochemistry of high-Mg andesites from Cape Vogel, Papua New Guinea: Chemical Geology, v. 33, p. 307-332.

Karpenko, S.F., Sharaskin, A.Y., Balashov, Y.A., Lyalikov, A.V., and Spiridonov, V.G., 1985, Isotopic and geochemical criteria for the origin of boninites: Geochemistry International, v. 22, p. 1-12.

Kay, R.W., 1980, Volcanic arc magmas: Implications of a melting-mixing model for element recycling in the crustupper mantle system: Journal of Petrology, v. 88, p. 497-522. 
Kay, R.W., 1984, Elemental abundances relevant to identification of magma sources: Philosophical Transactions of the Royal Society of London, Series A, v. 310, p. 535-547.

Kikuchi, Y. 1890, On pyroxenic components in certain volcanic rocks from Bonin Island: Journal of the College of Science, Imperial University, Japan, v. 3, p. 67-89.

Komatsu, M., 1980, Clinoenstatite in volcanic rocks from the Bonin Islands: Contributions to Mineralogy and Petrology, v. 74, p. 329-338.

Kretz, R., 1982, Transfer and exchange equilibria in a portion of the pyroxene quadrilateral as deduced from natural and experimental data: Geochimica et Cosmochimica Acta, v. 46, p. 411-421.

Kuroda, N., and Shiraki, K., 1975, Boninite and related rocks of Chichijima, Bonin Islands, Japan: Reports of Faculty of Science, Shizuoka University, v. 10, p. 145-155.

Kuroda, N., Shiraki, K., and Urano, H., 1978, Boninite as a possible calc-alkaline primary magma: Bulletin Volcanologique, v. 41, p. 563-575.

Kuroda, N., Shiraki, K., and Urano, H., 1984, Magma mixing and quartz-bearing boninites from Chichi-jima and Anishima, Bonin Islands: Memoirs of the Geological Society of Japan, v. 24, p. 157-164.

Kushiro, I., 1972, Effect of water on the composition of magmas formed at high pressures: Journal of Petrology, v. 13, p. 311-334.

Kushiro, I., 1974, Melting of hydrous upper mantle and possible generation of andesitic magmas: an approach from synthetic systems: Earth and Planetary Science Letters, v. 22, p. 294-299.

Lindsley, D.H., 1983, Pyroxene thermometry: American Mineralogist, v. 68, p. 477-493.

Lindsley, D.H., and Anderson, D.J., 1983, A two pyroxene thermometer: American Mineralogist, v. 88, p. 887-906.

Meijer, A., 1983, The origin of low-K rhyolites from the Mariana frontal arc: Contributions to Mineralogy and Petrology, v. 83, p. 45-51.

Nakamura, Y., 1971, Equilibrium relations in Mg-rich part of the pyroxene quadrilateral: Mineralogical Journal, v. 6, p. 264-276.

Nishido, H., and Otsuka, R., 1981, Chemical composition and physical properties of dachiardite group zeolites: Mineralogical Journal, v. 10, p. 371-384.

Nishido, H., and Otsuka, R., 1982, Two groups of heulandite from Chichijima, the Ogasawara Islands, Japan: Mineralogical Journal, v. 11, p. 1-14.

Perfit, M.R., Gust, D.A., Bence, A.E., Arculus, R.J., and Taylor, S.R., 1980, Chemical characteristics of island-arc basalts: Implications for mantle sources: Chemical Geology, v. 30, p. 227-256.

Petersen, J., 1891, Der boninit von Peel Island. Nachtrag zu den Bieträgen zur Petrographie von Sulphur Island: Jahrbuch der Hamburgishen Wissenschaftlichen Anstalten, v. 8, p. 341-349.

Sameshima, T., Paris, J.P., Black, P.M., and Heming, R.F., 1983, Clinoenstatite-bearing lavas from Nepoui, New Caledonia: American Mineralogist, v. 68, p. 1076-1082.

Sato, H., 1977, Nickel content of basaltic magmas: identification of primary magmas and a measure of the degree of olivine fractionation: Lithos, v. 10, p. 113-120. 
Shiraki, K., Kuroda, N., Maruyama, S., and Urano, H., 1978, Evolution of the Tertiary volcanic rocks in the IzuMariana arc: Bulletin Volcanologique, v. 41, p. 548-562.

Shiraki, K., Kuroda, N., Urano, H., and Maruyama, S., 1980, Clinoenstatite in boninites from the Bonin Islands, Japan: Nature, v. 285, p. 31-32.

Stern, R.J., Morris, J., Bloomer, S.H., and Hawkins, J.W., Jr., 1991, The source of the subduction component in convergent margin magmas: Trace element and radiogenic isotope evidence from Eocene boninites, Mariana forearc: Geochimica et Cosmochimica Acta, v. 55, p. 1467-1481.

Stewart, D.B., 1967, Four-phase curve in the system $\mathrm{CaAl}_{2} \mathrm{Si}_{2} \mathrm{O}_{8}-\mathrm{SiO}_{2}-\mathrm{H}_{2} \mathrm{O}$ between 1 and 10 kilobars, Schweizerische Mineralogische und Petrographische Mitteilungen, v. 47, p. 35-59.

Stolper, E., 1980, A phase diagram for mid-ocean ridge basalts: preliminary results and implications for petrogenesis: Contributions to Mineralogy and Petrology, v. 74, p. 13-27.

Stormer, J.G., and Nicholls, J., 1978, XLFRAC: A program for the interactive testing of magmatic differentiation models: Computers \& Geosciences, v. 4, p. 143-159.

Sun, S.S., and McDonough, W.F., 1989, Chemical and isotopic systematics of oceanic basalts: Implications for mantle composition and processes, in Saunders, A.D., and Norry, M.J., eds., Magmatism in the Ocean Basins: Geological Society Special Publication 42, Geological Society of London and Blackwell Scientific Publications, London, p. 313345 .

Sun, S., and Nesbitt, R.W., 1978, Geochemical regularities and genetic significance of ophiolitic basalts: Geology, v. 6, p. 689-693.

Tatsumi, Y., 1981, Melting experiments on a high magnesian andesite: Earth and Planetary Science Letters, v. 54, p. 356-365.

Tatsumi, Y., Hamilton, D.L., and Nesbitt, R.W., 1986, Chemical characteristics of fluid phase released from a subducted lithosphere and origin of arc magmas: Evidence from high-pressure experiments and natural rocks: Journal of Volcanology and Geothermal Research, v. 29, p. 293-309.

Tuttle, O.F., and Bowen, N.L., 1958, Origin of granite in the light of experimental studies in the system $\mathrm{NaAlSi}_{3} \mathrm{O}_{8}$ $\mathrm{KAlSi}_{3} \mathrm{O}_{8}-\mathrm{SiO}_{2}-\mathrm{H}_{2} \mathrm{O}$ : Geological Society of America Memoir, v. 74, 153 p.

Umino, S., 1985, Volcanic geology of Chichijima, the Bonin Islands (Ogasawara Islands): Journal of the Geological Society of Japan, v. 91, p. 505-523.

Umino, S., 1986, Magma mixing in boninite sequence of Chichijima, Bonin Islands: Journal of Volcanology and Geothermal Research, v. 29, p. 125-157.

Umino, S., and Kushiro, I., 1989, Experimental studies on boninite petrogenesis, in Crawford, A. J., ed., Boninites: London, UK, Unwin Hyman, p. 89-111.

Van der Laan, S.R., Flower, M.F.J., and Koster van Groos, A.F., 1989, Experimental evidence for the origin of boninites: near-liquidus phase relations to $7.5 \mathrm{kbar}$, in Crawford, A. J., ed., Boninites: London, UK, Unwin Hyman, p. $112-147$.

Walker, D.A., and Cameron, W.E., 1983, Boninite primary magmas: Evidence from the Cape Vogel Peninsula, PNG: Contributions to Mineralogy and Petrology, v. 83, p. 150-158.

Walker, D., Shibata, T., and De Long, S.F., 1979, Abyssal tholeiites from the Oceanographer Fracture Zone. II. Phase equilibrium and mixing: Contributions to Mineralogy and Petrology, v. 70, p. 111-125. 
Wells, P.R.A., 1977, Pyroxene geothermometry in simple and complex systems: Contributions to Mineralogy and Petrology, v. 62, p. 129-139.

Yoder, H.S., Jr., 1968, Albite-anorthite-quartz-water at 5 kb: Carnegie Institution of Washington Yearbook, v. 66, p. 477-478.

Yoder, H.S., Jr., and Tilley, C.E., 1962, Origin of basalt magmas: an experimental study of natural and synthetic rock systems: Journal of Petrology, v. 3, p. 342-532. 


\section{Figures}

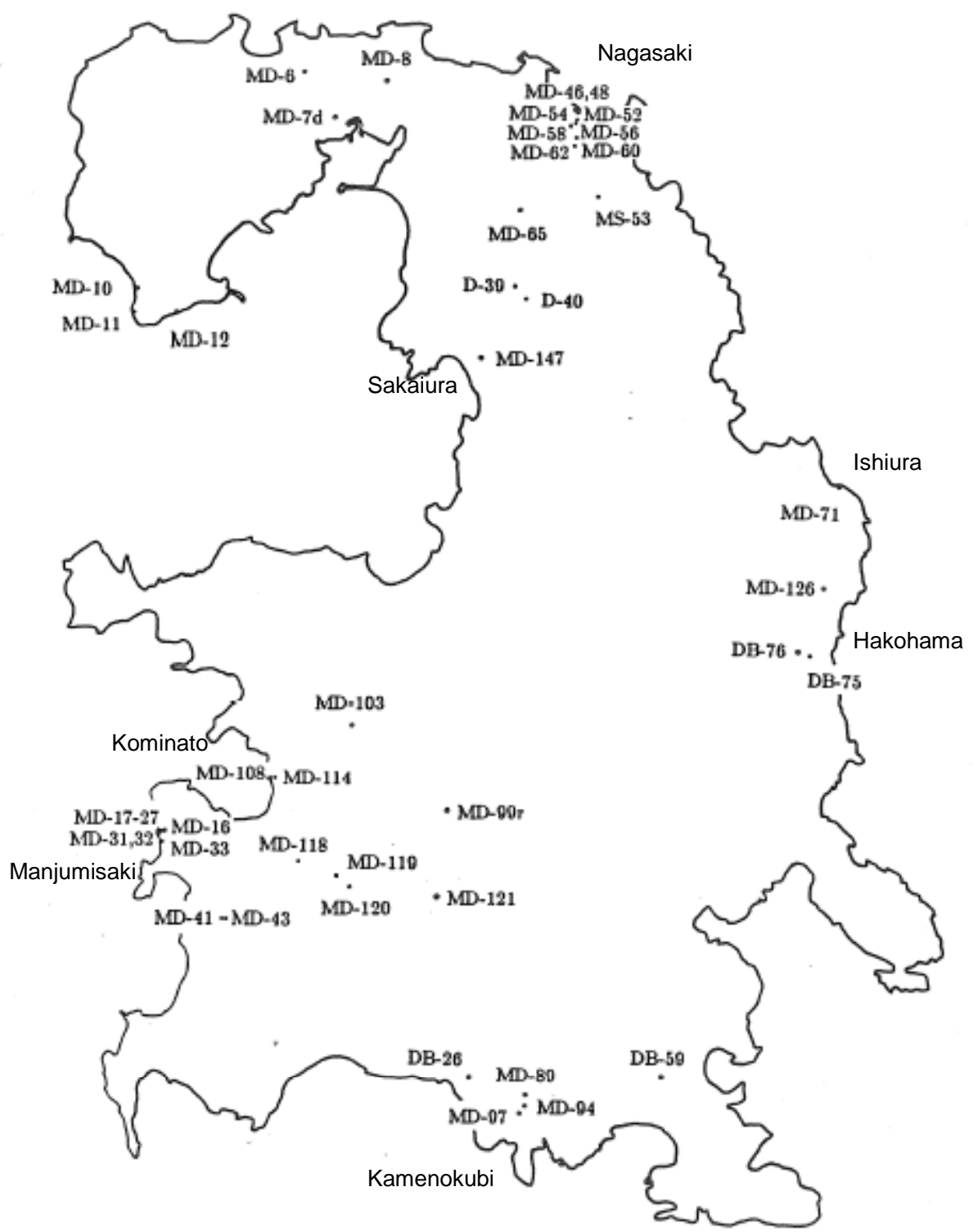

Fig. 1. Sample location map of Chichi-jima. 


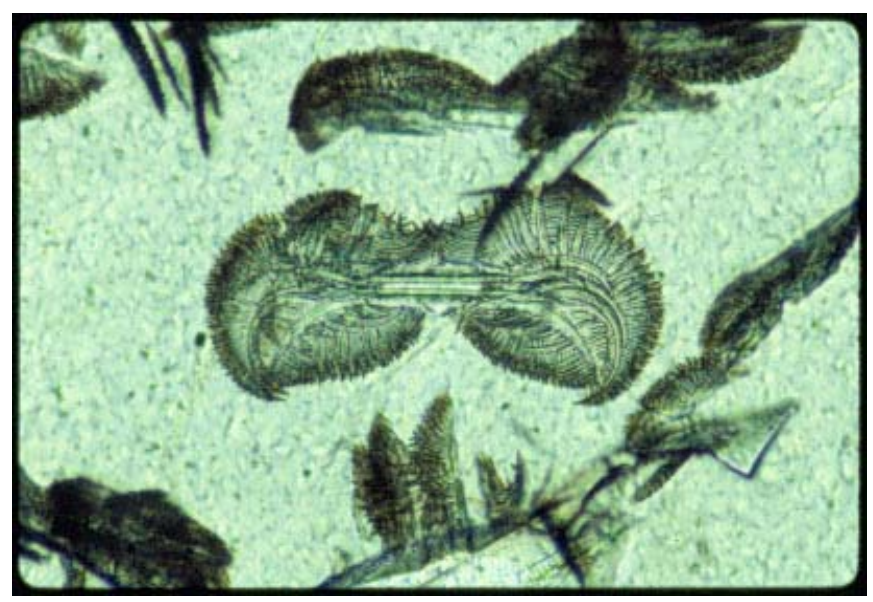

Fig. 2. Photomicrograph (uncrossed nicols) of feathery pyroxene quench crystals in boninite sample MD-94. Photograph is $0.72 \mathrm{~mm}$ long.

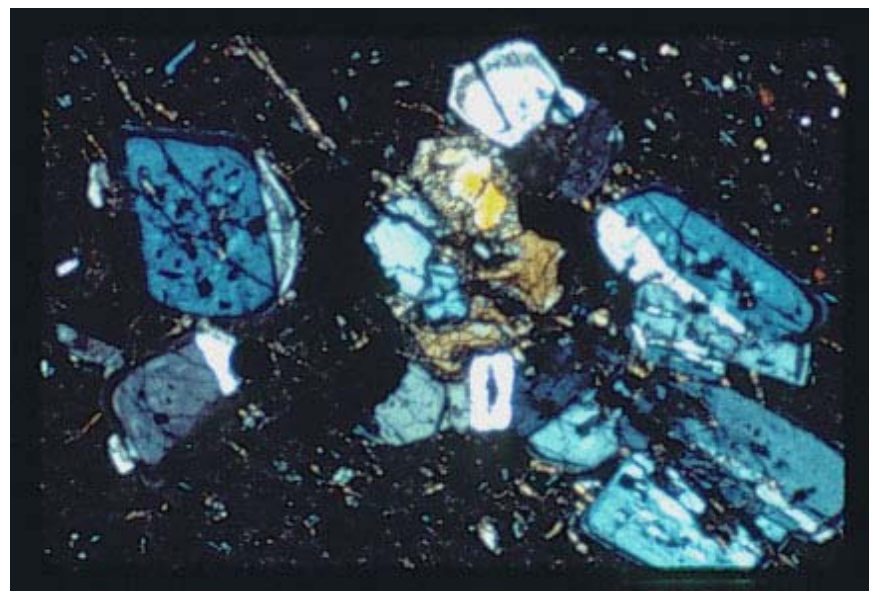

Fig. 3. Photomicrograph (crossed nicols) of quartz dacite lava (MD-65). Note frittered plagioclase and glomeroporphyritic texture. Photograph is $3.2 \mathrm{~mm}$ long. 

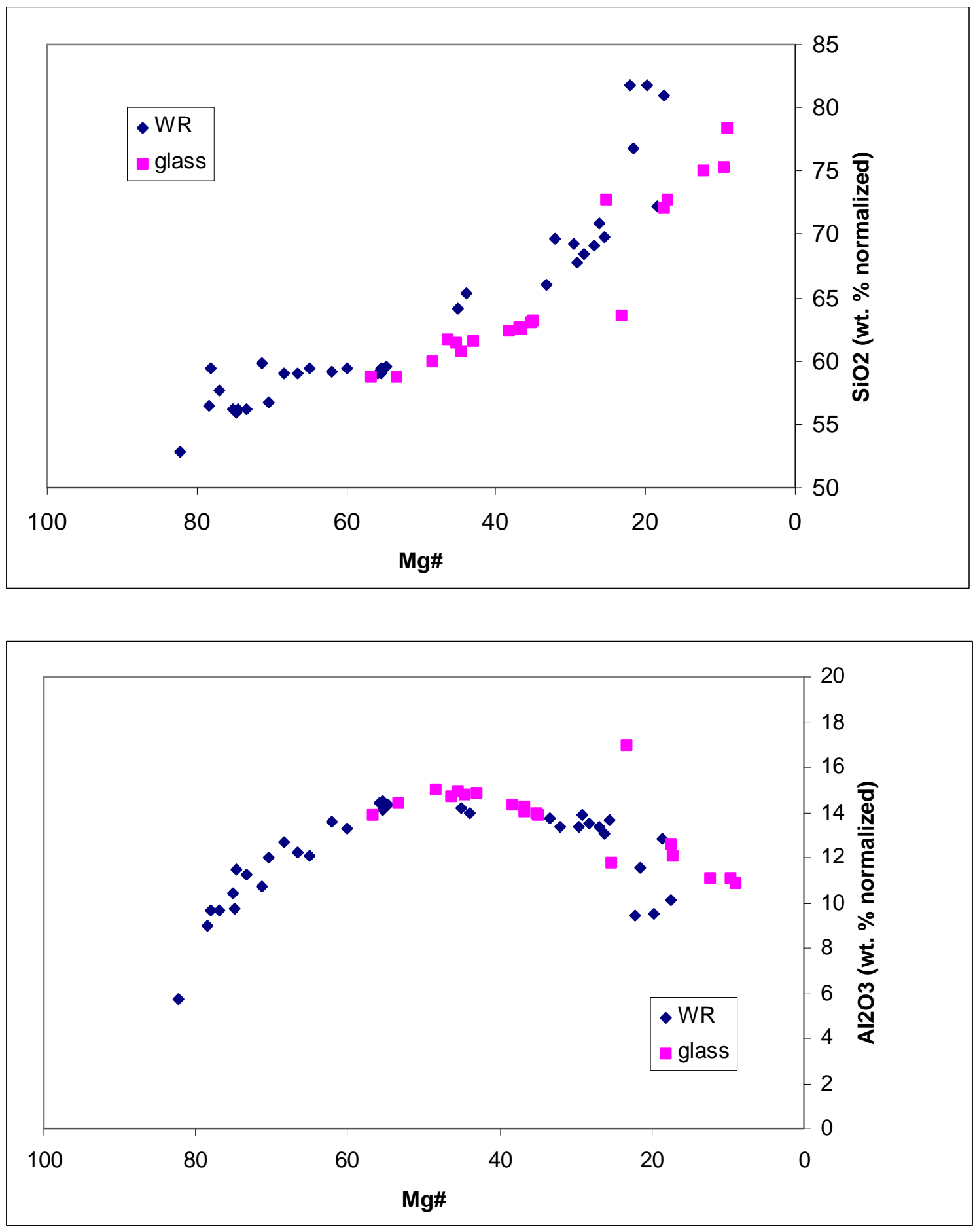

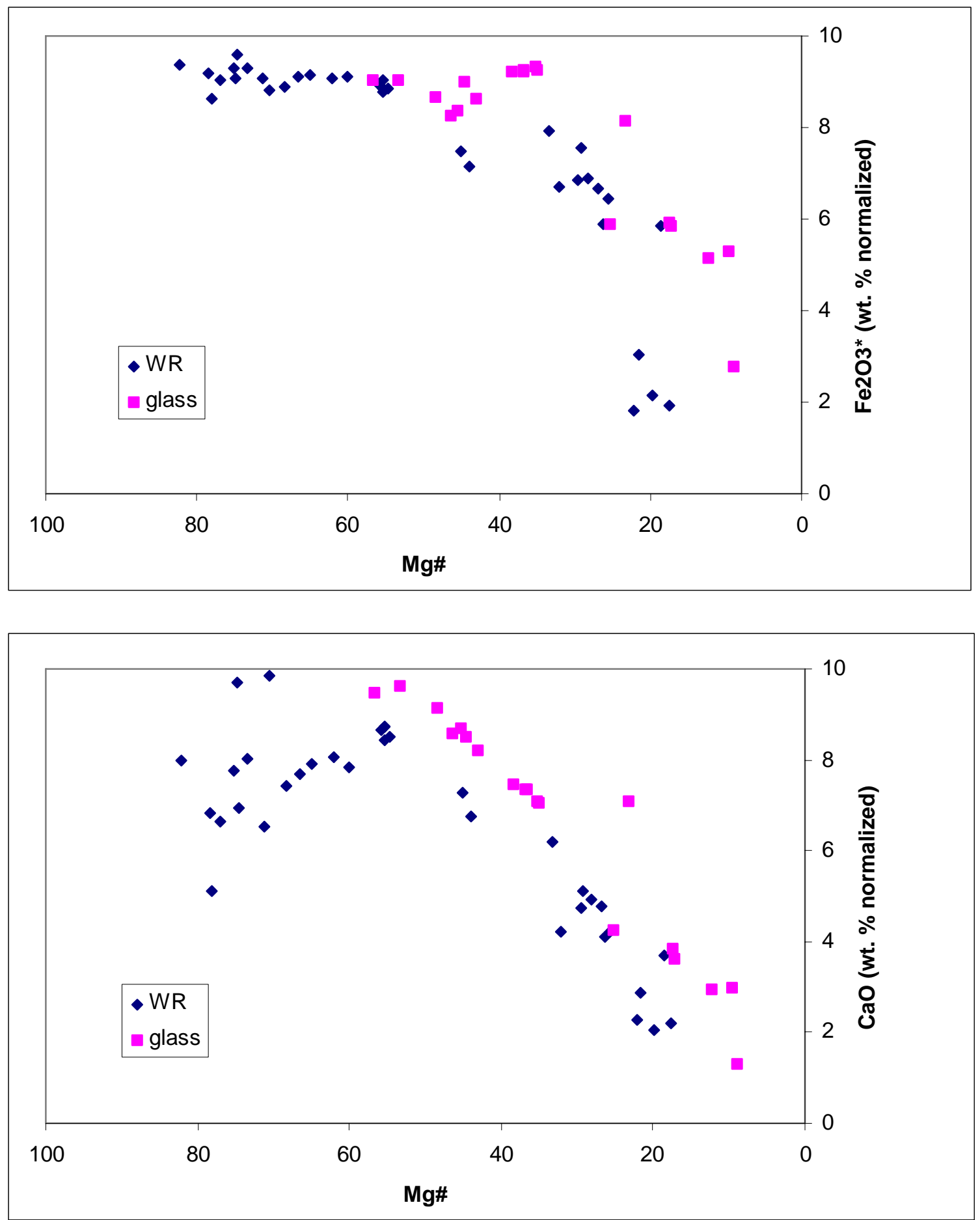

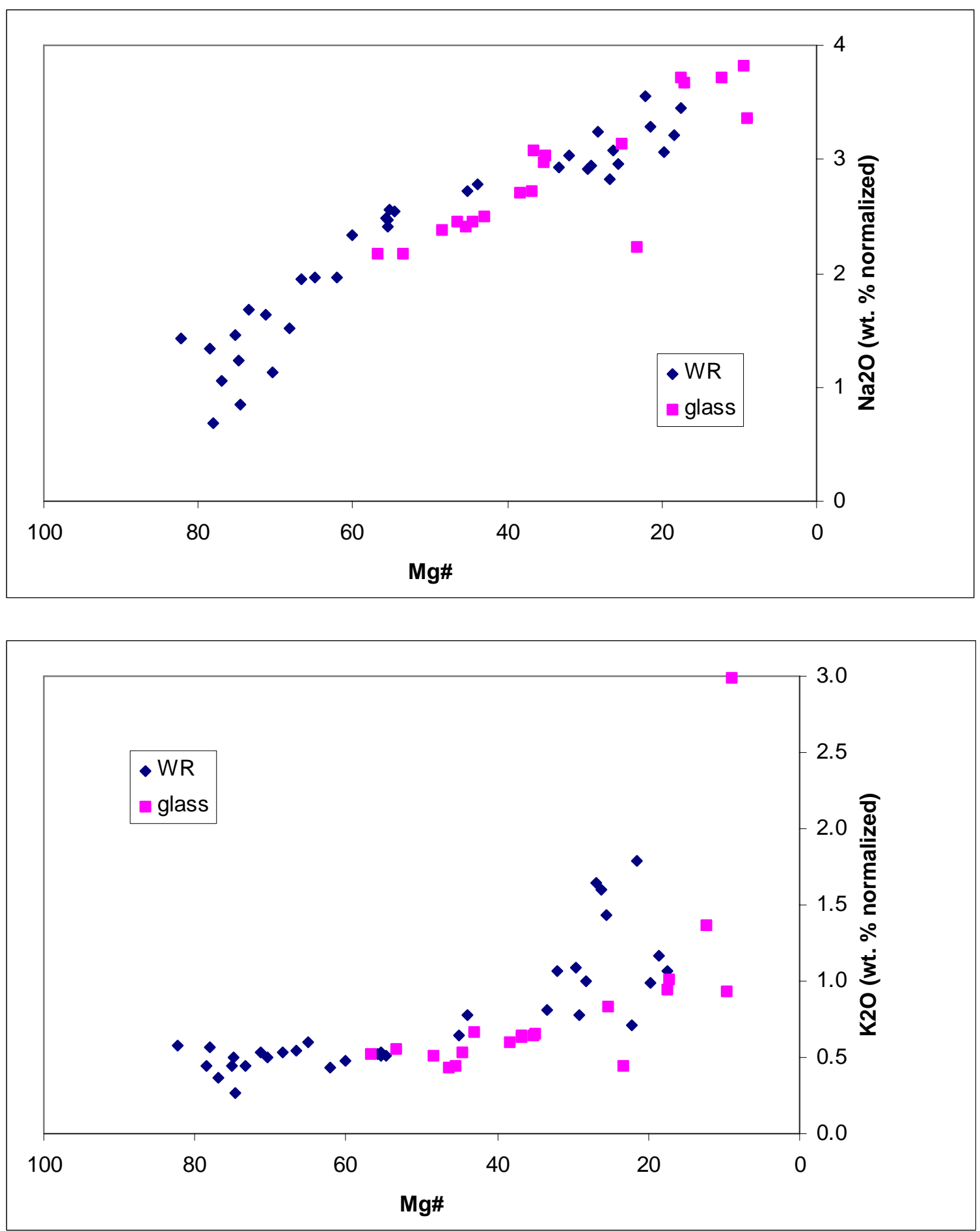

Fig. 4. Major element variation in whole-rock and glass samples. Analyses are normalized to $100 \%$ anhydrous with all iron as $\mathrm{Fe}_{2} \mathrm{O}_{3}{ }^{*}$, and are plotted versus $\mathrm{Mg}$ number $\left(\mathrm{Mg} \#=\left(100 \mathrm{MgO} /\left(\mathrm{MgO}+\mathrm{FeO}{ }^{*}\right)\right)\right.$ molar $)$, where $\mathrm{FeO}^{*}=$ total $\mathrm{Fe}$ as $\mathrm{FeO}$. 


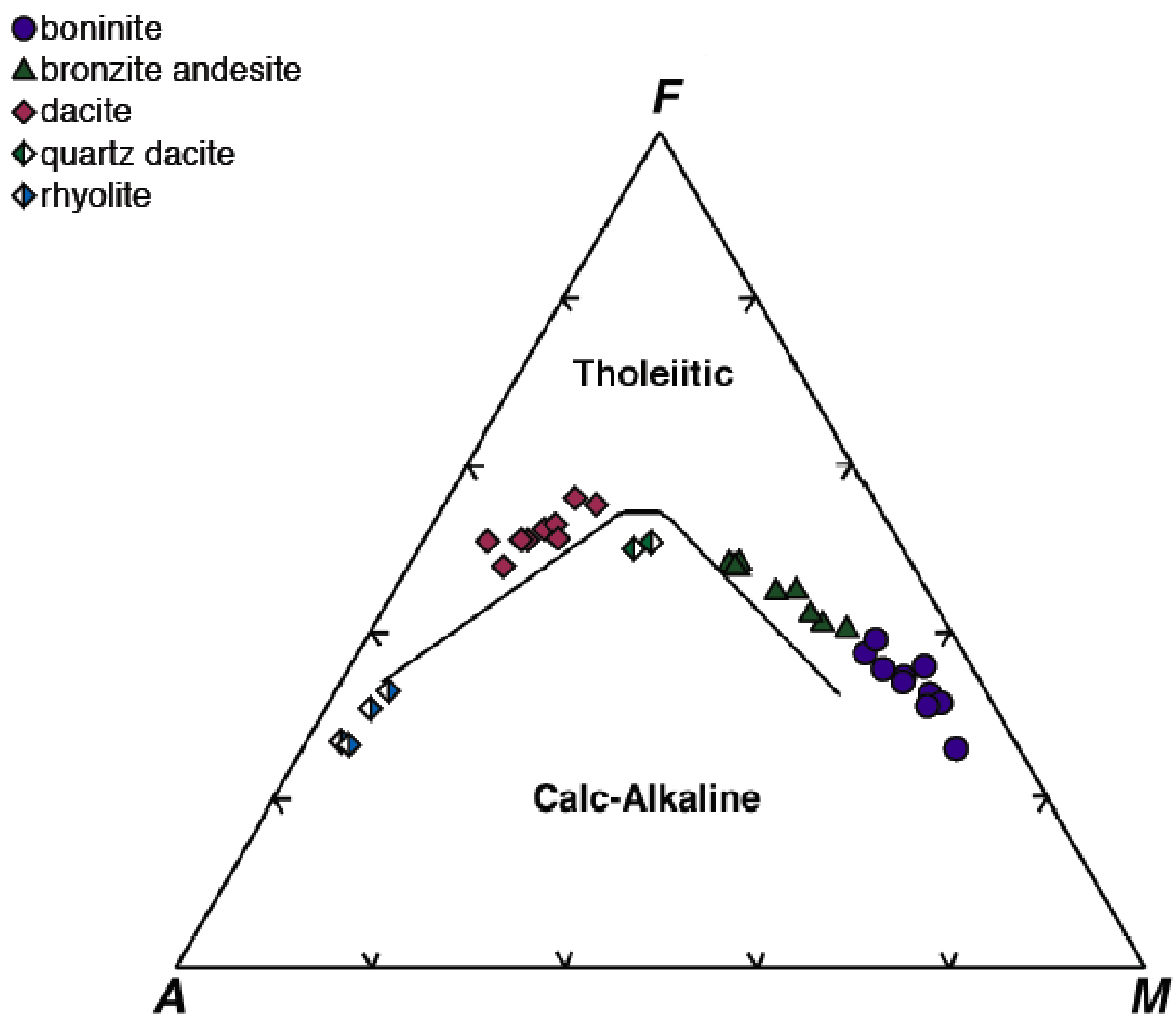

Fig. 5. AFM diagram. $A=\mathrm{Na}_{2} \mathrm{O}+\mathrm{K}_{2} \mathrm{O}, \mathrm{F}=$ total iron as $\mathrm{FeO}, \mathrm{M}=\mathrm{MgO}$, in wt. \%. Boundary for tholeiite and calc-alkaline magma suites from Irvine and Baragar (1971). 

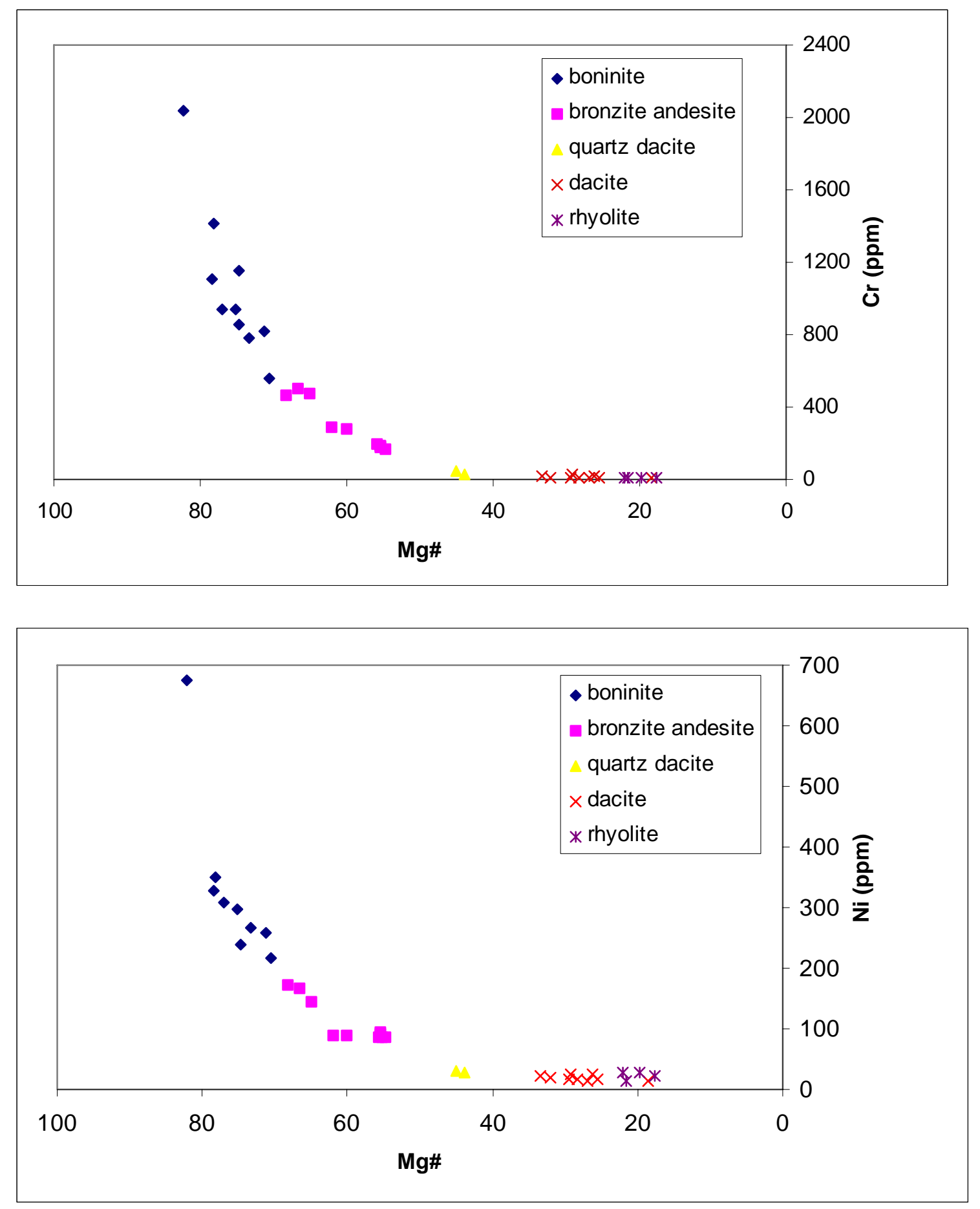

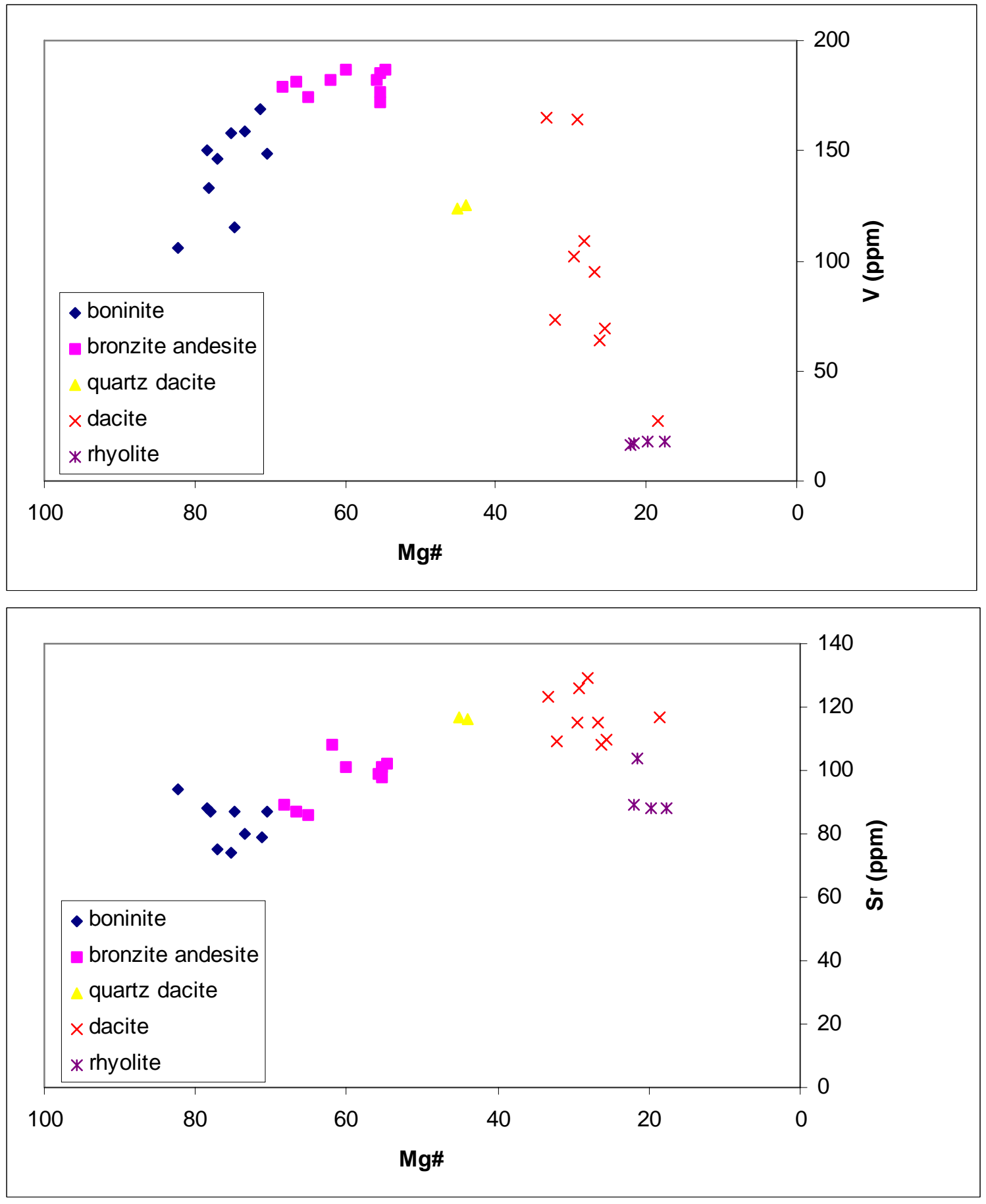

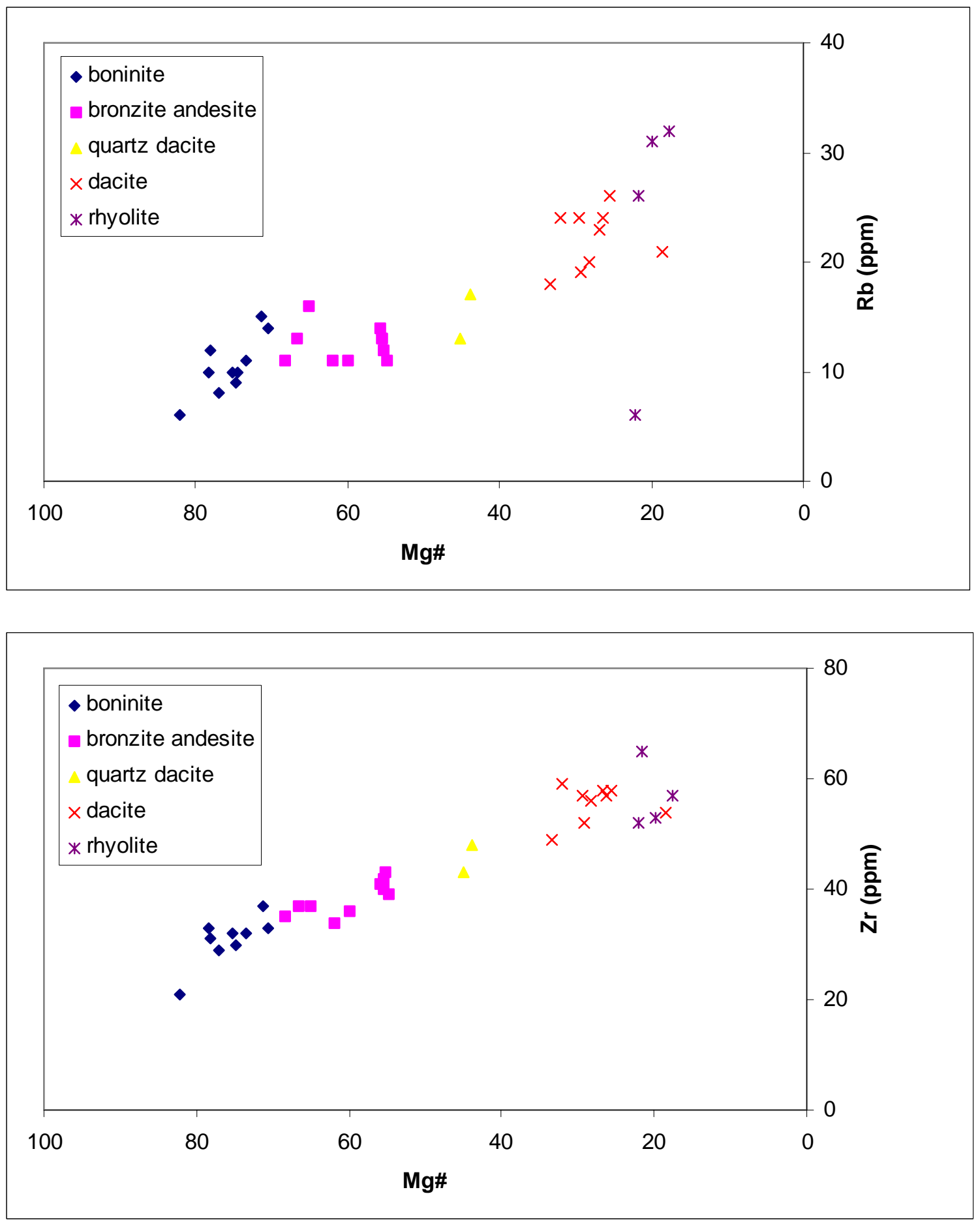

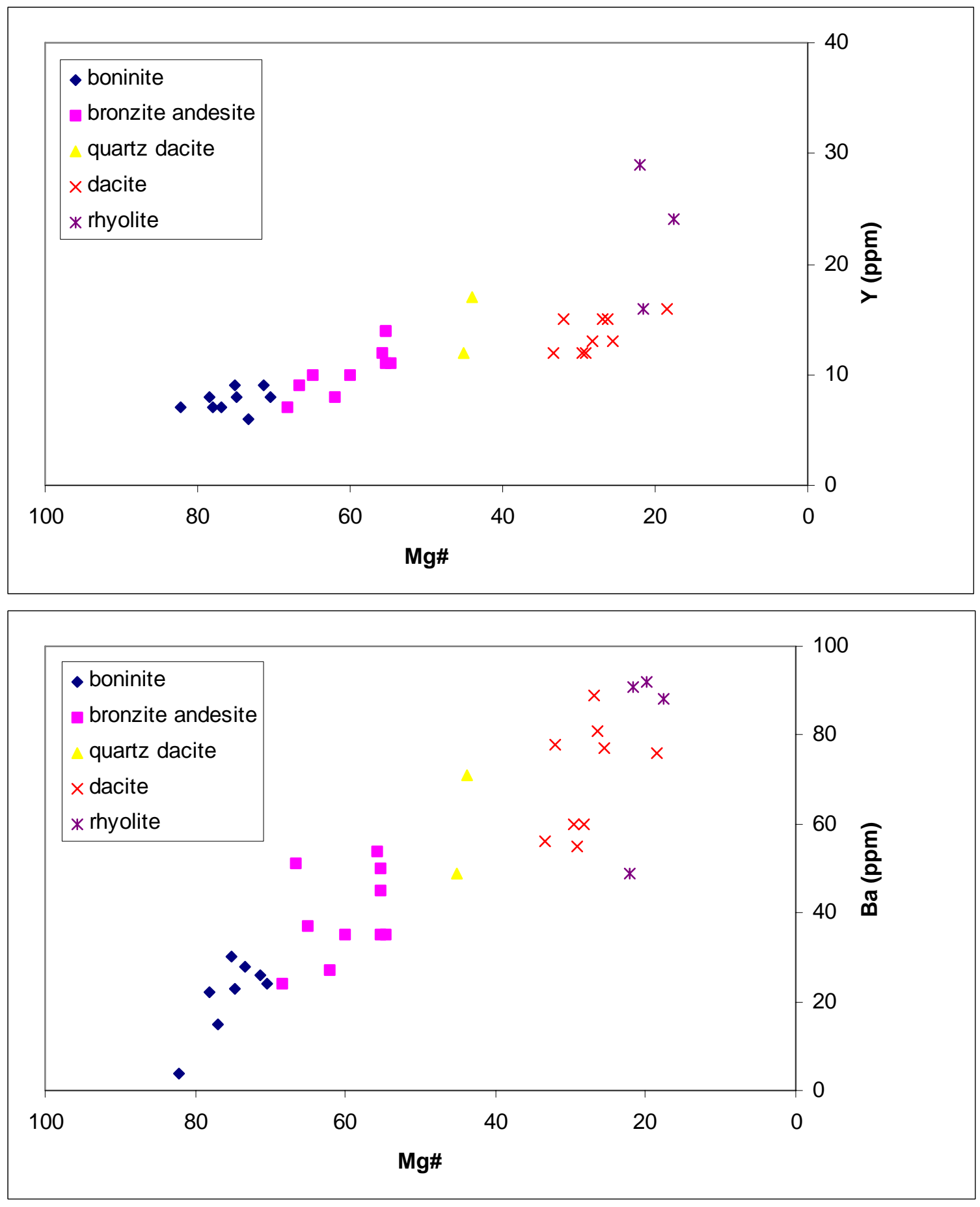

Fig. 6. Trace element variation for whole-rock samples. Analyses are plotted versus Mg number. 

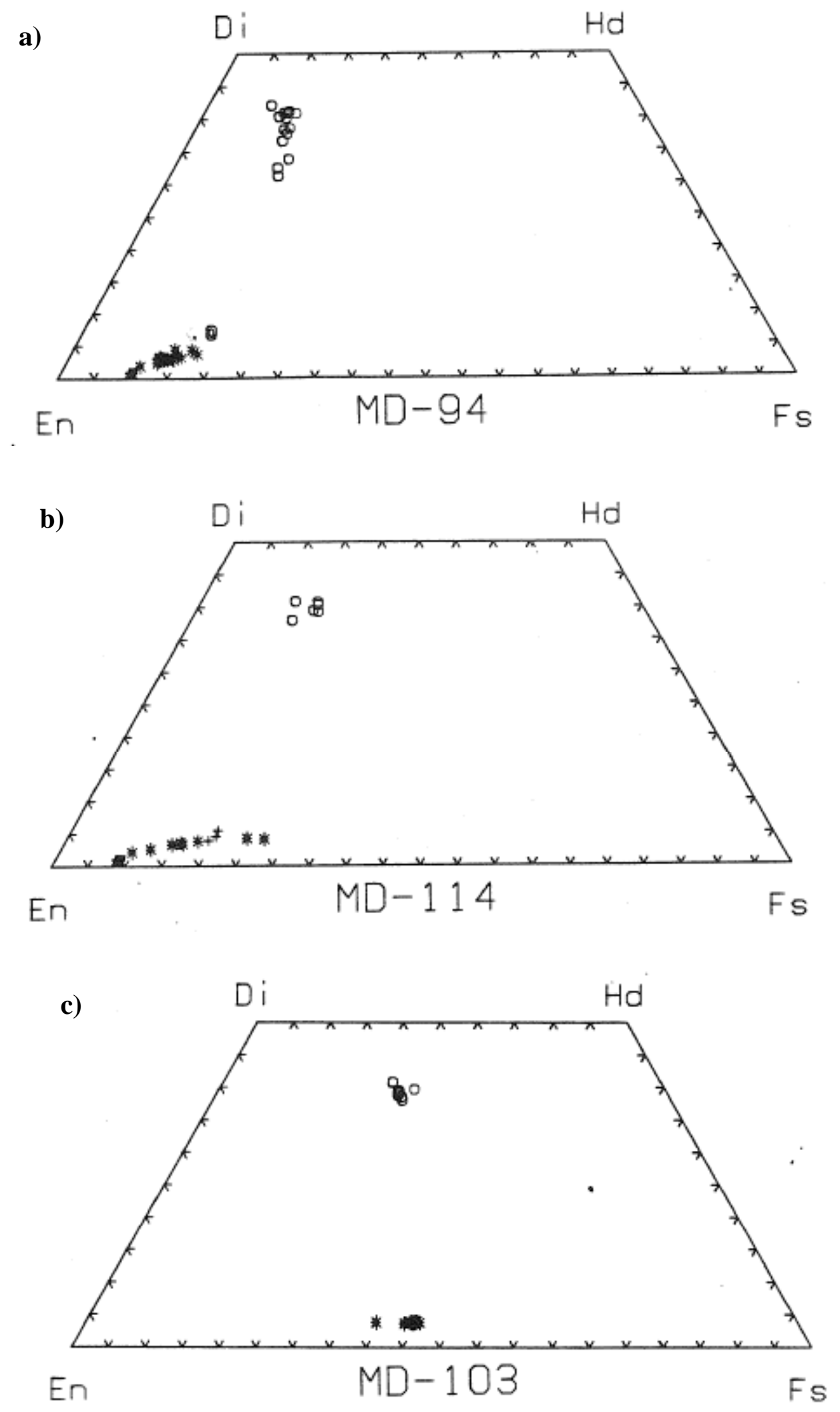

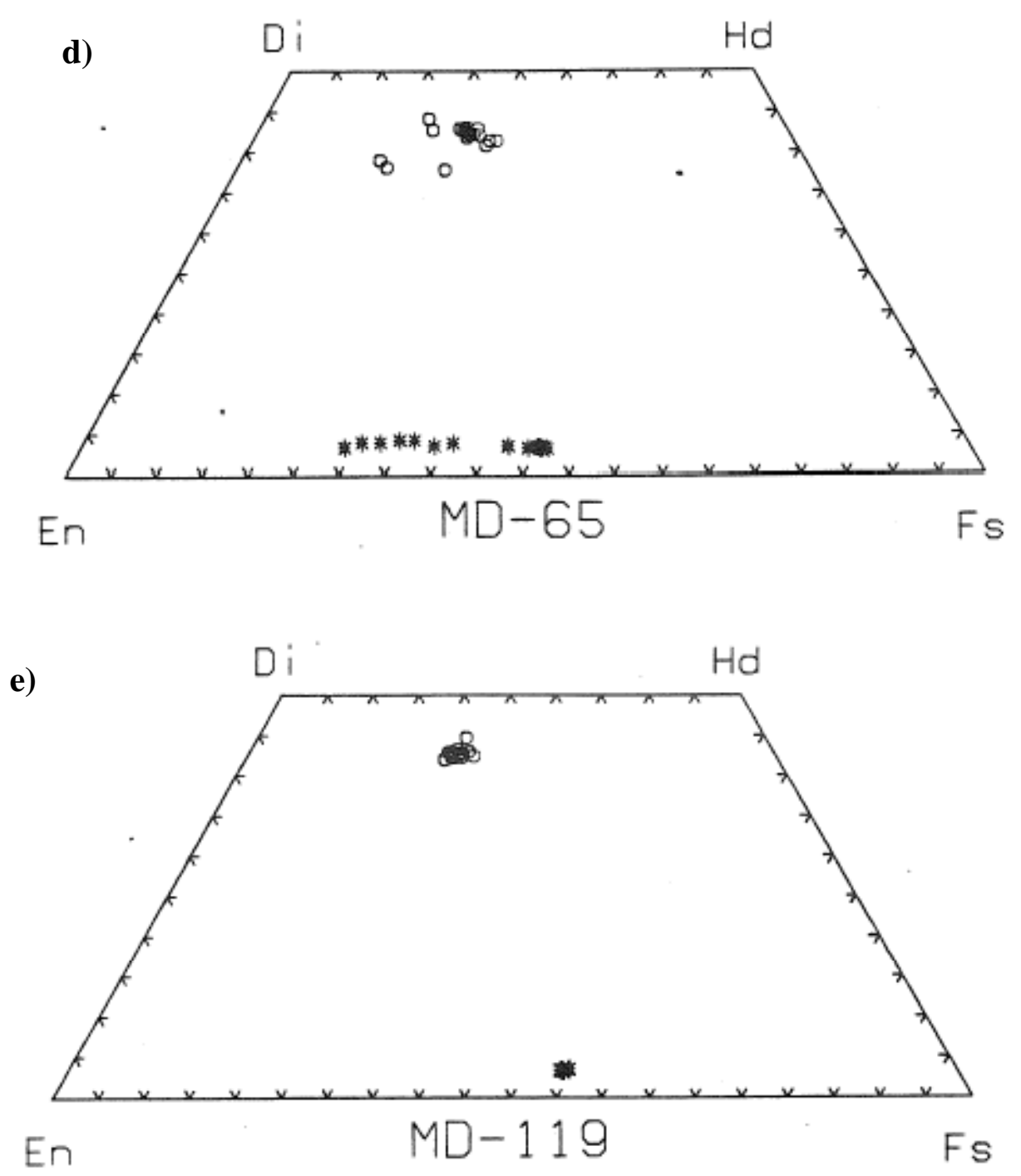

Fig. 7. Quadrilateral pyroxene diagrams. $a=$ boninite,$b=$ bronzite andesite, $c=$ dacite,$d=$ quartz dacite, e = rhyolite; \#- clinoenstatite, ${ }^{*}$ - orthopyroxene, + - bronzite rims on clinoenstatite, $@$ - pigeonite, o - augite. 

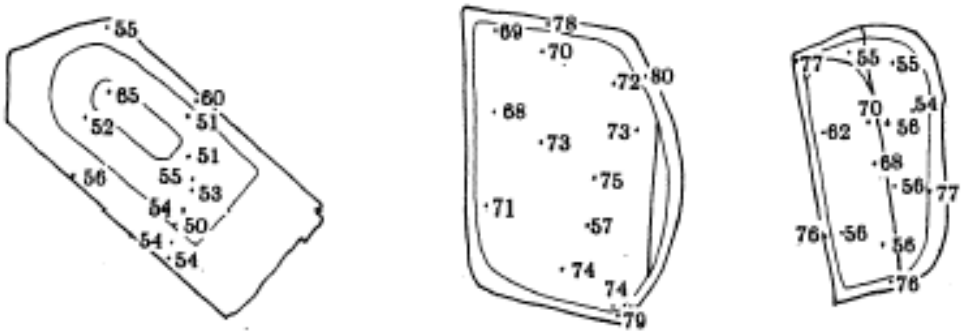

a)
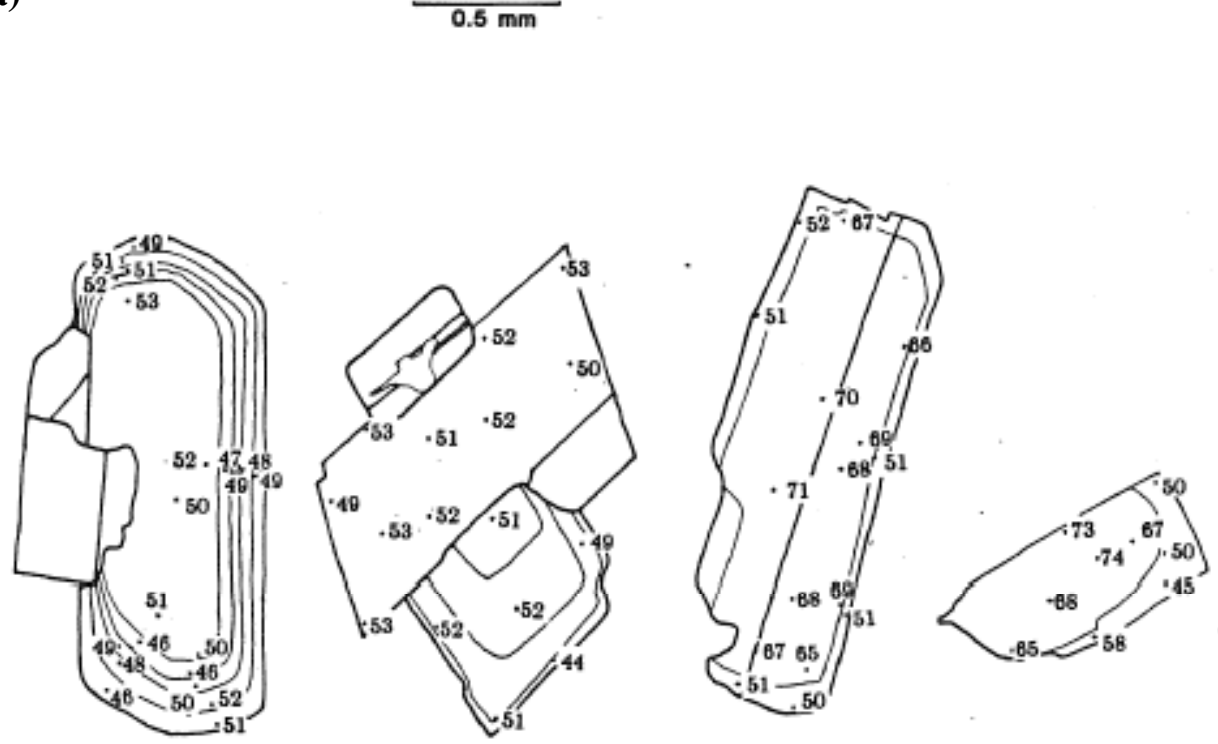

b)

$0.5 \mathrm{~mm}$

Fig. 8. Compositional zonations for plagioclase in (a) quartz dacite and (b) rhyolite lavas. Numbers give An content for microprobe spot analyses. 

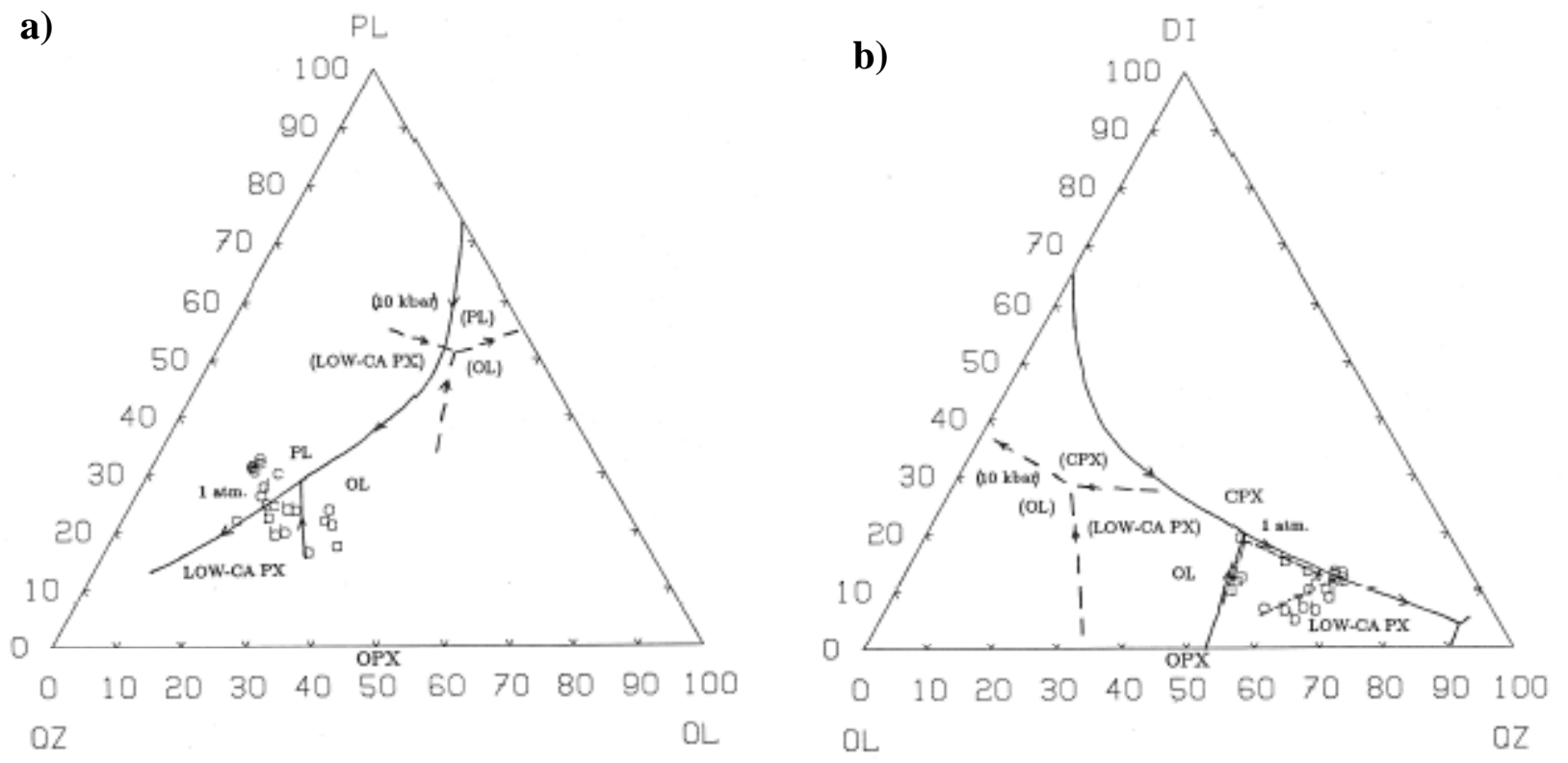

Fig. 9. Ternary projections for the system plagioclase-diopside-olivine-quartz. Pseudo-liquidus curves from Walker et al., 1979 (solid lines, $1 \mathrm{~atm}$ ) and Stolper, 1980 (dashed lines, $10 \mathrm{kbar}$ ). Dot-dash lines indicate two possible magma evolution paths. 


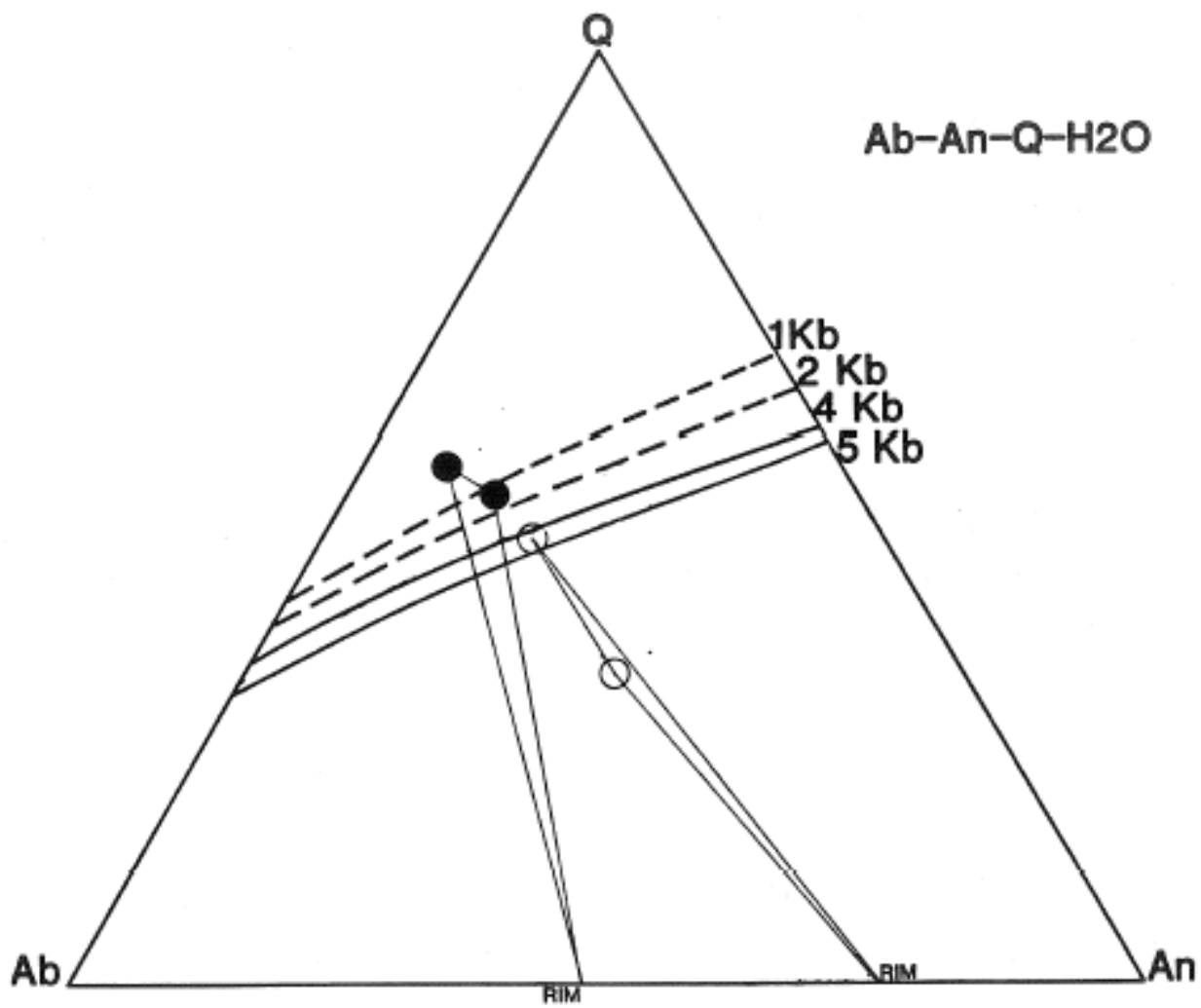

Fig. 10. Ternary representation of the anorthite-albite-quartz- $\mathrm{H}_{2} \mathrm{O}$ system. Experimental liquidus curves from Tuttle and Bowen (1958), Stewart (1967), Yoder (1968), and Hoffmann (1976). Quartz dacite (MD-65 open circles) and rhyolite (MD-119 - closed circles) whole-rock and glass compositions are projected using CIPW normative mineral compositions. Tie lines connect whole-rock, glass, and feldspar rim compositions. 
Table 1 - Whole-Rock Major and Trace Element Analyses

\begin{tabular}{|c|c|c|c|c|c|c|c|c|c|c|}
\hline & \multicolumn{10}{|c|}{ Boninite } \\
\hline & MD-52 & MD-54 & MD-56 & MD-71 & MD-94 & MD-97 & MD-126 & DB-75 & DB-76 & MS-53 ${ }^{\mathrm{a}}$ \\
\hline $\mathrm{SiO}_{2}$ & 52.8 & 54.4 & 57.0 & 50.3 & 54.1 & 54.1 & 53.4 & 55.4 & 53.8 & 56.2 \\
\hline $\mathrm{TiO}_{2}$ & 0.10 & 0.10 & 0.13 & 0.08 & 0.12 & 0.11 & 0.14 & 0.13 & 0.14 & 0.20 \\
\hline $\mathrm{Al}_{2} \mathrm{O}_{3}$ & 9.16 & 9.13 & 10.21 & 5.44 & 10.81 & 10.04 & 11.27 & 9.02 & 8.52 & 11.46 \\
\hline $\mathrm{Fe}_{2} \mathrm{O}_{3} *$ & 8.55 & 8.54 & 8.66 & 8.90 & 8.95 & 8.96 & 8.30 & 8.03 & 8.76 & 9.60 \\
\hline $\mathrm{MnO}$ & 0.16 & 0.13 & 0.12 & 0.20 & 0.13 & 0.13 & 0.10 & 0.13 & 0.14 & 0.22 \\
\hline $\mathrm{MgO}$ & 12.81 & 14.47 & 10.86 & 20.69 & 12.46 & 13.71 & 10.03 & 14.46 & 15.63 & 14.23 \\
\hline $\mathrm{CaO}$ & 9.17 & 6.27 & 6.23 & 7.59 & 7.73 & 7.47 & 9.25 & 4.76 & 6.49 & 6.94 \\
\hline $\mathrm{Na}_{2} \mathrm{O}$ & 1.17 & 1.00 & 1.56 & 1.36 & 1.62 & 1.41 & 1.06 & 0.64 & 1.27 & 0.84 \\
\hline $\mathrm{K}_{2} \mathrm{O}$ & 0.47 & 0.35 & 0.51 & 0.55 & 0.43 & 0.43 & 0.47 & 0.53 & 0.42 & 0.27 \\
\hline $\mathrm{P}_{2} \mathrm{O}_{5}$ & 0.01 & 0.00 & 0.01 & 0.01 & 0.03 & 0.02 & 0.02 & 0.00 & 0.01 & 0.01 \\
\hline Total & 94.35 & 94.43 & 95.31 & 95.12 & 96.35 & 96.36 & 94.03 & 93.16 & 95.18 & 99.97 \\
\hline $\mathrm{Q}$ & 6.38 & 10.09 & 14.37 & -- & 6.41 & 6.27 & 10.90 & 14.79 & 5.94 & 11.39 \\
\hline Or & 2.97 & 2.21 & 3.19 & 3.45 & 2.66 & 2.66 & 2.98 & 3.39 & 2.63 & 1.60 \\
\hline $\mathrm{Ab}$ & 10.57 & 9.04 & 13.96 & 12.20 & 14.34 & 12.48 & 9.61 & 5.86 & 11.38 & 7.19 \\
\hline $\mathrm{An}$ & 19.60 & 20.71 & 20.47 & 7.54 & 21.92 & 20.71 & 26.37 & 21.83 & 17.27 & 26.88 \\
\hline $\mathrm{Di}$ & 23.22 & 10.02 & 9.81 & 25.71 & 14.47 & 14.38 & 18.30 & 2.98 & 13.41 & 6.18 \\
\hline Нy & 35.46 & 46.15 & 36.34 & 33.83 & 38.27 & 41.61 & 29.96 & 49.39 & 47.47 & 42.94 \\
\hline $\mathrm{Ol}$ & -- & -- & -- & 15.47 & -- & -- & -- & -- & -- & $\begin{array}{ll}-- \\
-\end{array}$ \\
\hline $\mathrm{Mt}$ & 1.58 & 1.58 & 1.58 & 1.63 & 1.61 & 1.62 & 1.54 & 1.51 & 1.60 & 3.42 \\
\hline Il & 0.20 & 0.20 & 0.26 & 0.16 & 0.24 & 0.22 & 0.29 & 0.27 & 0.28 & 0.38 \\
\hline $\mathrm{Ap}$ & 0.03 & -- & 0.03 & 0.03 & 0.07 & 0.05 & 0.05 & -- & 0.03 & 0.02 \\
\hline $\mathrm{Cr}$ & 854 & 941 & 815 & 2036 & 777 & 936 & 556 & 1415 & 1103 & 1150 \\
\hline $\mathrm{Ni}$ & 240 & 308 & 258 & 676 & 266 & 297 & 218 & 350 & 327 & \\
\hline $\mathrm{V}$ & 115 & 146 & 169 & 106 & 159 & 158 & 149 & 133 & 150 & \\
\hline $\mathrm{Rb}$ & 9 & 8 & 15 & 6 & 11 & 10 & 14 & 12 & 10 & 10 \\
\hline $\mathrm{Sr}$ & 87 & 75 & 79 & 94 & 80 & 74 & 87 & 87 & 88 & \\
\hline $\mathrm{Zr}$ & 30 & 29 & 37 & 21 & 32 & 32 & 33 & 31 & 33 & \\
\hline $\mathrm{Y}$ & 8 & 7 & 9 & 7 & 6 & 9 & 8 & 7 & 8 & \\
\hline $\mathrm{Ba}$ & 23 & 15 & 26 & 4 & 28 & 30 & 24 & 22 & na & \\
\hline $\mathrm{Mg} \#$ & 74.8 & 77.0 & 71.3 & 82.2 & 73.4 & 75.2 & 70.5 & 78.1 & 78.4 & 74.6 \\
\hline
\end{tabular}

Total Fe reported as $\mathrm{Fe}_{2} \mathrm{O}_{3}{ }^{*}$. ${ }^{\text {a }}$-Shiraki et al., 1980 (sample 2 from Table 1). Analysis recalculated reporting all $\mathrm{Fe}$ as $\mathrm{Fe}_{2} \mathrm{O}_{3}$ and $100 \%$ anhydrous. 
Table 1 (cont.)

\begin{tabular}{|c|c|c|c|c|c|c|c|c|c|c|}
\hline & \multicolumn{10}{|c|}{ Bronzite Andesite } \\
\hline & MD-16 & MD-31 & MD-32 & MD-46 & MD-48 & MD-58 & MD-60 & MD-62 & MD-108 & MD-114 \\
\hline $\mathrm{SiO}_{2}$ & 56.4 & 57.0 & 56.8 & 56.9 & 57.1 & 57.3 & 57.2 & 57.2 & 57.2 & 57.0 \\
\hline $\mathrm{TiO}_{2}$ & 0.14 & 0.13 & 0.13 & 0.21 & 0.21 & 0.22 & 0.21 & 0.22 & 0.14 & 0.14 \\
\hline $\mathrm{Al}_{2} \mathrm{O}_{3}$ & 12.08 & 11.77 & 11.54 & 13.88 & 14.03 & 13.78 & 13.78 & 13.59 & 12.81 & 13.12 \\
\hline $\mathrm{Fe}_{2} \mathrm{O}_{3}$ * & 8.50 & 8.79 & 8.75 & 8.61 & 8.56 & 8.71 & 8.49 & 8.43 & 8.77 & 8.74 \\
\hline $\mathrm{MnO}$ & 0.11 & 0.12 & 0.12 & 0.12 & 0.11 & 0.11 & 0.12 & 0.11 & 0.11 & 0.12 \\
\hline $\mathrm{MgO}$ & 9.23 & 8.84 & 8.21 & 5.49 & 5.33 & 5.46 & 5.17 & 5.30 & 6.89 & 7.19 \\
\hline $\mathrm{CaO}$ & 7.08 & 7.43 & 7.57 & 8.34 & 8.46 & 8.16 & 8.19 & 8.38 & 7.55 & 7.78 \\
\hline $\mathrm{Na}_{2} \mathrm{O}$ & 1.45 & 1.88 & 1.88 & 2.40 & 2.47 & 2.32 & 2.45 & 2.37 & 2.25 & 1.89 \\
\hline $\mathrm{K}_{2} \mathrm{O}$ & 0.51 & 0.53 & 0.57 & 0.50 & 0.49 & 0.51 & 0.49 & 0.50 & 0.46 & 0.42 \\
\hline $\mathrm{P}_{2} \mathrm{O}_{5}$ & 0.02 & 0.02 & 0.03 & 0.04 & 0.04 & 0.04 & 0.04 & 0.03 & 0.03 & 0.02 \\
\hline Total & 95.54 & 96.50 & 95.60 & 96.48 & 96.80 & 96.57 & 96.10 & 96.17 & 96.23 & 96.41 \\
\hline $\mathrm{Q}$ & 14.84 & 13.28 & 14.07 & 13.74 & 13.65 & 14.78 & 14.70 & 14.81 & 14.20 & 14.99 \\
\hline Or & 3.18 & 3.27 & 3.55 & 3.09 & 3.02 & 3.15 & 3.04 & 3.10 & 2.85 & 2.60 \\
\hline $\mathrm{Ab}$ & 12.95 & 16.62 & 16.78 & 21.21 & 21.76 & 20.48 & 21.73 & 21.02 & 19.95 & 16.72 \\
\hline $\mathrm{An}$ & 26.32 & 23.10 & 22.53 & 26.77 & 26.81 & 26.79 & 26.37 & 26.17 & 24.62 & 27.26 \\
\hline $\mathrm{Di}$ & 8.58 & 12.39 & 13.71 & 13.31 & 13.68 & 12.49 & 13.14 & 14.16 & 11.79 & 10.58 \\
\hline $\mathrm{Hy}$ & 32.25 & 29.46 & 27.43 & 19.82 & 19.03 & 20.21 & 18.97 & 18.71 & 24.66 & 25.96 \\
\hline Mt & 1.55 & 1.59 & 1.59 & 1.55 & 1.54 & 1.57 & 1.54 & 1.52 & 1.58 & 1.58 \\
\hline Il & 0.28 & 0.26 & 0.26 & 0.42 & 0.42 & 0.44 & 0.42 & 0.44 & 0.28 & 0.28 \\
\hline $\mathrm{Ap}$ & 0.05 & 0.05 & 0.08 & 0.10 & 0.10 & 0.10 & 0.10 & 0.07 & 0.07 & 0.05 \\
\hline $\mathrm{Cr}$ & 469 & 506 & 471 & 195 & 187 & 187 & 165 & 178 & 282 & 285 \\
\hline $\mathrm{Ni}$ & 171 & 167 & 145 & 86 & 86 & 94 & 87 & 93 & 88 & 89 \\
\hline $\mathrm{V}$ & 179 & 181 & 174 & 182 & 185 & 177 & 187 & 172 & 187 & 182 \\
\hline $\mathrm{Rb}$ & 11 & 13 & 16 & 14 & 12 & 13 & 11 & 13 & 11 & 11 \\
\hline $\mathrm{Sr}$ & 89 & 87 & 86 & 99 & 101 & 98 & 102 & 101 & 101 & 108 \\
\hline $\mathrm{Zr}$ & 35 & 37 & 37 & 41 & 43 & 40 & 39 & 42 & 36 & 34 \\
\hline Y & 7 & 9 & 10 & 12 & 11 & 14 & 11 & 14 & 10 & 8 \\
\hline $\mathrm{Ba}$ & 24 & 51 & 37 & 54 & 45 & 35 & 35 & 50 & 35 & 27 \\
\hline Mg\# & 68.3 & 66.6 & 65.0 & 55.8 & 55.3 & 55.4 & 54.7 & 55.4 & 60.0 & 62.0 \\
\hline
\end{tabular}


Table 1 (cont.)

\begin{tabular}{|l|l|l|l|l|l|l|l|l|l|}
\hline & \multicolumn{9}{|c|}{ Dacite } \\
\hline & MD-6 & MD-7D & MD-41 & MD-43 & MD-89 & MD-99r & MD-103 & MD-121 & DB-26 \\
\hline $\mathrm{SiO}_{2}$ & 66.3 & 63.6 & 66.7 & 66.3 & 68.7 & 67.1 & 67.6 & 68.5 & 64.9 \\
\hline $\mathrm{TiO}_{2}$ & 0.24 & 0.20 & 0.22 & 0.21 & 0.22 & 0.23 & 0.22 & 0.23 & 0.25 \\
\hline $\mathrm{Al}_{2} \mathrm{O}_{3}$ & 13.10 & 13.24 & 12.93 & 12.80 & 12.68 & 12.91 & 13.23 & 12.17 & 13.28 \\
\hline $\mathrm{Fe}_{2} \mathrm{O}_{3}{ }^{*}$ & 6.68 & 7.65 & 6.42 & 6.57 & 5.71 & 6.47 & 6.24 & 5.55 & 7.22 \\
\hline $\mathrm{MnO}$ & 0.10 & 0.11 & 0.09 & 0.09 & 0.08 & 0.10 & 0.09 & 0.09 & 0.09 \\
\hline $\mathrm{MgO}$ & 1.33 & 1.93 & 1.19 & 1.39 & 1.03 & 1.54 & 1.08 & 0.63 & 1.50 \\
\hline $\mathrm{CaO}$ & 4.78 & 5.97 & 4.6 & 4.54 & 3.99 & 4.07 & 4.09 & 3.51 & 4.89 \\
\hline $\mathrm{Na}_{2} \mathrm{O}$ & 3.14 & 2.82 & 2.73 & 2.79 & 2.98 & 2.93 & 2.87 & 3.04 & 2.82 \\
\hline $\mathrm{K}_{2} \mathrm{O}$ & 0.97 & 0.78 & 1.59 & 1.04 & 1.55 & 1.03 & 1.39 & 1.11 & 0.74 \\
\hline $\mathrm{P}_{2} \mathrm{O}_{5}$ & 0.05 & 0.04 & 0.06 & 0.04 & 0.05 & 0.05 & 0.05 & 0.05 & 0.03 \\
\hline $\mathrm{Total}$ & 96.78 & 96.35 & 96.55 & 95.81 & 97.01 & 96.40 & 96.86 & 94.85 & 95.75 \\
\hline $\mathrm{Q}$ & 30.32 & 26.91 & 31.55 & 32.62 & 33.85 & 32.86 & 32.98 & 37.17 & 30.76 \\
\hline $\mathrm{Or}$ & 5.96 & 4.82 & 9.79 & 6.46 & 9.49 & 6.35 & 8.53 & 6.95 & 4.60 \\
\hline $\mathrm{Ab}$ & 27.63 & 24.94 & 24.07 & 24.80 & 26.13 & 25.86 & 25.22 & 27.26 & 25.09 \\
\hline $\mathrm{An}$ & 19.70 & 22.12 & 19.10 & 20.31 & 17.25 & 19.85 & 19.84 & 17.25 & 22.50 \\
\hline $\mathrm{Di}$ & 3.94 & 7.27 & 3.66 & 2.63 & 2.51 & 0.74 & 0.76 & 0.74 & 2.40 \\
\hline $\mathrm{Hy}$ & 10.64 & 12.07 & 10.10 & 11.48 & 9.19 & 12.59 & 11.00 & 9.06 & 12.77 \\
\hline $\mathrm{Mt}$ & 1.21 & 1.38 & 1.15 & 1.19 & 1.02 & 1.17 & 1.11 & 1.01 & 1.31 \\
\hline $\mathrm{Il}$ & 0.47 & 0.40 & 0.44 & 0.42 & 0.43 & 0.46 & 0.43 & 0.44 & 0.50 \\
\hline $\mathrm{Ap}$ & 0.12 & 0.10 & 0.15 & 0.10 & 0.12 & 0.12 & 0.12 & 0.13 & 0.08 \\
\hline $\mathrm{Cr}$ & 11 & 15 & 10 & 12 & 14 & 12 & 10 & 11 & 24 \\
\hline $\mathrm{Ni}$ & 17 & 21 & 13 & 16 & 26 & 20 & 18 & 15 & 24 \\
\hline $\mathrm{V}$ & 109 & 165 & 95 & 102 & 64 & 73 & 69 & 27 & 164 \\
\hline $\mathrm{Rb}$ & 20 & 18 & 23 & 24 & 24 & 24 & 26 & 21 & 19 \\
\hline $\mathrm{Sr}$ & 129 & 123 & 115 & 115 & 108 & 109 & 110 & 117 & 126 \\
\hline $\mathrm{Zr}$ & 56 & 49 & 58 & 57 & 57 & 59 & 58 & 54 & 52 \\
\hline $\mathrm{Y}$ & 13 & 12 & 15 & 12 & 15 & 15 & 13 & 16 & 12 \\
\hline $\mathrm{Ba}$ & 60 & 56 & 89 & 60 & 81 & 78 & 77 & 76 & 55 \\
\hline $\mathrm{Mg} \#$ & 28.2 & 33.3 & 26.8 & 29.5 & 26.3 & 32.1 & 25.6 & 18.5 & 29.2 \\
\hline & & & & & & & & & \\
\hline
\end{tabular}


Table 1 (cont.)

\begin{tabular}{|l|l|l|l|l|l|l|}
\hline & \multicolumn{2}{|c|}{ Quartz Dacite } & \multicolumn{5}{c|}{ Rhyolite } \\
\hline & MD-65 & D-40 & MD-118 & MD-119 & MD-120 & DB-59 \\
\hline $\mathrm{SiO}_{2}$ & 61.4 & 62.5 & 76.6 & 72.6 & 78.4 & 77.7 \\
\hline $\mathrm{TiO}_{2}$ & 0.19 & 0.19 & 0.12 & 0.14 & 0.11 & 0.12 \\
\hline $\mathrm{Al}_{2} \mathrm{O}_{3}$ & 13.60 & 13.36 & 9.54 & 10.94 & 9.13 & 8.98 \\
\hline $\mathrm{Fe}_{2} \mathrm{O}_{3}{ }^{*}$ & 7.16 & 6.84 & 1.84 & 2.86 & 2.07 & 1.73 \\
\hline $\mathrm{MnO}$ & 0.11 & 0.10 & 0.01 & 0.05 & 0.01 & 0.01 \\
\hline $\mathrm{MgO}$ & 2.97 & 2.71 & 0.20 & 0.40 & 0.26 & 0.25 \\
\hline $\mathrm{CaO}$ & 6.96 & 6.44 & 2.07 & 2.71 & 1.95 & 2.16 \\
\hline $\mathrm{Na}_{2} \mathrm{O}$ & 2.61 & 2.66 & 3.27 & 3.11 & 2.94 & 3.37 \\
\hline $\mathrm{K}_{2} \mathrm{O}$ & 0.62 & 0.74 & 1.01 & 1.69 & 0.95 & 0.68 \\
\hline $\mathrm{P}_{2} \mathrm{O}_{5}$ & 0.05 & 0.05 & 0.03 & 0.04 & 0.03 & 0.02 \\
\hline $\mathrm{Total}$ & 95.67 & 95.59 & 94.66 & 94.54 & 95.85 & 94.97 \\
\hline $\mathrm{Q}$ & 23.75 & 25.60 & 51.15 & 42.99 & 54.45 & 52.97 \\
\hline $\mathrm{Or}$ & 3.80 & 4.61 & 6.32 & 10.59 & 5.87 & 4.24 \\
\hline $\mathrm{Ab}$ & 23.24 & 23.70 & 29.28 & 27.91 & 26.01 & 30.06 \\
\hline $\mathrm{An}$ & 24.83 & 23.51 & 8.86 & 11.56 & 9.31 & 7.77 \\
\hline $\mathrm{Di}$ & 9.38 & 8.18 & 1.62 & 2.09 & 0.51 & 2.92 \\
\hline $\mathrm{Hy}$ & 13.22 & 12.66 & 2.14 & 3.96 & 3.17 & 1.43 \\
\hline $\mathrm{Mt}$ & 1.30 & 1.24 & 0.34 & 0.52 & 0.38 & 0.32 \\
\hline $\mathrm{Il}$ & 0.38 & 0.38 & 0.24 & 0.28 & 0.22 & 0.24 \\
\hline $\mathrm{Ap}$ & 0.10 & 0.13 & 0.05 & 0.10 & 0.07 & 0.05 \\
\hline $\mathrm{Cr}$ & 45 & 32 & 5 & 8 & 7 & 8 \\
\hline $\mathrm{Ni}$ & 30 & 28 & 21 & 13 & 27 & 28 \\
\hline $\mathrm{V}$ & 124 & 125 & 18 & 17 & 18 & 16 \\
\hline $\mathrm{Rb}$ & 13 & 17 & 32 & 26 & 31 & 6 \\
\hline $\mathrm{Sr}$ & 117 & 116 & 88 & 104 & 88 & 89 \\
\hline $\mathrm{Zr}$ & 43 & 48 & 57 & 65 & 53 & 52 \\
\hline $\mathrm{Y}$ & 12 & 17 & 24 & 16 & 64 & 29 \\
\hline $\mathrm{Ba}$ & 49 & 71 & 88 & 91 & 92 & 49 \\
\hline $\mathrm{Mg} \#$ & 45.1 & 43.9 & 17.6 & 21.6 & 19.8 & 22.1 \\
\hline & & & & & & \\
\hline
\end{tabular}


Table 2 - Glass Major Element Analyses

\begin{tabular}{|c|c|c|c|c|c|c|c|c|c|c|}
\hline & \multicolumn{4}{|c|}{ Boninite } & \multicolumn{6}{|c|}{ Bronzite Andesite } \\
\hline & MD-94 & MD-97 & MD-126 & MS-53 & MD-16 & MD-31 & MD-46 & MD-48 & MD-58 & MD-60 \\
\hline $\mathrm{SiO}_{2}$ & 56.3 & 56.6 & 57.8 & 60.1 & 58.7 & 59.3 & 60.7 & 61.3 & 59.5 & 60.0 \\
\hline $\mathrm{TiO}_{2}$ & 0.09 & 0.10 & 0.17 & 0.14 & 0.17 & 0.14 & 0.25 & 0.28 & 0.26 & 0.24 \\
\hline $\mathrm{Al}_{2} \mathrm{O}_{3}$ & 13.78 & 13.39 & 14.49 & 16.01 & 14.27 & 14.31 & 13.41 & 13.52 & 13.54 & 13.82 \\
\hline $\mathrm{FeO}^{*}$ & 7.79 & 7.85 & 7.52 & 6.92 & 7.84 & 7.47 & 8.09 & 8.08 & 7.88 & 7.97 \\
\hline $\mathrm{MnO}$ & 0.11 & 0.09 & 0.11 & 0.07 & 0.12 & 0.09 & 0.08 & 0.13 & 0.08 & 0.13 \\
\hline $\mathrm{MgO}$ & 5.01 & 5.79 & 3.97 & 1.18 & 3.54 & 3.16 & 2.47 & 2.45 & 2.58 & 2.78 \\
\hline $\mathrm{CaO}$ & 9.22 & 9.15 & 8.81 & 6.70 & 8.23 & 7.90 & 6.83 & 6.85 & 6.96 & 7.19 \\
\hline $\mathrm{Na}_{2} \mathrm{O}$ & 2.08 & 2.09 & 2.30 & 2.11 & 2.37 & 2.41 & 2.86 & 2.95 & 2.58 & 2.60 \\
\hline $\mathrm{K}_{2} \mathrm{O}$ & 0.53 & 0.50 & 0.49 & 0.42 & 0.52 & 0.64 & 0.62 & 0.64 & 0.61 & 0.58 \\
\hline Total & 94.91 & 95.56 & 95.66 & 93.65 & 95.76 & 95.42 & 95.31 & 96.20 & 93.99 & 95.31 \\
\hline \multirow[t]{3}{*}{$\mathrm{Mg} \#$} & 53.4 & 56.8 & 48.5 & 23.3 & 44.6 & 43.0 & 35.2 & 35.1 & 36.9 & 38.3 \\
\hline & \multicolumn{3}{|c|}{ Bronzite Andesite } & \multicolumn{4}{|l|}{ Dacite } & \multicolumn{2}{|c|}{ Quartz Dacite } & Rhyolite \\
\hline & MD-62 & MD-108 & MD-114 & MD-43 & MD-99r & MD-103 & MD-121 & MD-65 & & MD-119 \\
\hline $\mathrm{SiO}_{2}$ & 59.4 & 59.3 & 59.0 & 66.7 & 66.0 & 68.1 & 66.7 & 69.4 & & 73.8 \\
\hline $\mathrm{TiO}_{2}$ & 0.25 & 0.14 & 0.13 & 0.21 & 0.19 & 0.20 & 0.20 & 0.20 & & 0.15 \\
\hline $\mathrm{Al}_{2} \mathrm{O}_{3}$ & 13.29 & 14.14 & 14.33 & 11.08 & 11.54 & 10.08 & 9.86 & 11.25 & & 10.22 \\
\hline $\mathrm{FeO}^{*}$ & 7.91 & 7.15 & 7.24 & 4.82 & 4.89 & 4.21 & 4.23 & 5.07 & & 2.34 \\
\hline $\mathrm{MnO}$ & 0.13 & 0.09 & 0.10 & 0.07 & 0.06 & 0.09 & 0.07 & 0.10 & & 0.06 \\
\hline $\mathrm{MgO}$ & 2.57 & 3.47 & 3.38 & 0.56 & 0.58 & 0.33 & 0.25 & 0.96 & & 0.13 \\
\hline $\mathrm{CaO}$ & 6.96 & 8.24 & 8.36 & 3.33 & 3.53 & 2.68 & 2.63 & 4.05 & & 1.22 \\
\hline $\mathrm{Na}_{2} \mathrm{O}$ & 2.92 & 2.36 & 2.31 & 3.37 & 3.41 & 3.38 & 3.39 & 2.99 & & 3.16 \\
\hline $\mathrm{K}_{2} \mathrm{O}$ & 0.60 & 0.42 & 0.43 & 0.93 & 0.87 & 1.24 & 0.83 & 0.80 & & 2.81 \\
\hline Total & 94.03 & 95.31 & 95.28 & 91.07 & 91.07 & 90.31 & 88.16 & 94.82 & & 93.89 \\
\hline $\mathrm{Mg} \#$ & 36.7 & 45.4 & 45.4 & 17.2 & 17.5 & 12.3 & 9.5 & 25.2 & & 9.0 \\
\hline
\end{tabular}

Total $\mathrm{Fe}$ given as $\mathrm{FeO}^{*}$. Glass compositions represent average of 10 spot analyses per sample. 
Table 3 - Olivine Analyses

\begin{tabular}{|l|l|l|}
\hline & MS-53 & MD-71 \\
\hline $\mathrm{SiO}_{2}$ & 40.65 & 41.23 \\
\hline $\mathrm{MgO}$ & 49.36 & 50.39 \\
\hline $\mathrm{FeO}$ & 9.23 & 7.78 \\
\hline $\mathrm{MnO}$ & 0.16 & 0.13 \\
\hline $\mathrm{Cr}_{2} \mathrm{O}_{3}$ & 0.09 & 0.11 \\
\hline $\mathrm{CaO}$ & & 0.13 \\
\hline $\mathrm{NiO}$ & 0.20 & 0.27 \\
\hline $\mathrm{Na}{ }_{2} \mathrm{O}$ & 0.03 & \\
\hline $\mathrm{Total}$ & 99.72 & 100.04 \\
\hline $\mathrm{Mg} \#$ & 90.5 & 92.0 \\
\hline & Structural Composition (4 Oxygens) \\
\hline $\mathrm{Si}$ & 0.997 & 1.001 \\
\hline $\mathrm{Mg}$ & 1.805 & 1.824 \\
\hline $\mathrm{Fe}$ & 0.189 & 0.158 \\
\hline $\mathrm{Mn}$ & 0.003 & 0.003 \\
\hline $\mathrm{Cr}$ & 0.002 & 0.002 \\
\hline $\mathrm{Ca}$ & & 0.003 \\
\hline $\mathrm{Ni}$ & 0.004 & 0.004 \\
\hline $\mathrm{Na}$ & 0.001 & \\
\hline & & \\
\hline
\end{tabular}


Table 4 - Spinel Analyses

\begin{tabular}{|c|c|c|c|c|c|c|c|}
\hline & MD- $48^{\mathrm{a}}$ & MD- $48^{b}$ & MD- $48^{\mathrm{c}}$ & MD-31 & MD-31 & MD-97 & MD-97 \\
\hline $\mathrm{SiO}_{2}$ & 0.10 & 0.13 & 0.12 & 0.04 & 0.08 & 0.09 & 0.11 \\
\hline $\mathrm{Al}_{2} \mathrm{O}_{3}$ & 7.08 & 5.79 & 5.76 & 9.24 & 5.39 & 10.68 & 6.15 \\
\hline $\mathrm{TiO}_{2}$ & 0.13 & 0.06 & 0.04 & 0.10 & 0.06 & 0.10 & 0.05 \\
\hline $\mathrm{FeO}$ & 18.54 & 17.88 & 24.07 & 22.63 & 23.77 & 18.97 & 19.63 \\
\hline $\mathrm{Fe}_{2} \mathrm{O}_{3}$ & 5.04 & 1.42 & 2.57 & 8.02 & 3.23 & 6.99 & 2.61 \\
\hline $\mathrm{MnO}$ & 0.39 & 0.41 & 0.49 & 0.38 & 0.51 & 0.37 & 0.39 \\
\hline $\mathrm{MgO}$ & 9.15 & 9.41 & 5.60 & 6.87 & 5.71 & 9.28 & 8.40 \\
\hline $\mathrm{Cr}_{2} \mathrm{O}_{3}$ & 58.26 & 63.31 & 63.30 & 57.65 & 61.38 & 52.61 & 61.63 \\
\hline $\mathrm{CaO}$ & 0.02 & 0.00 & 0.00 & 0.02 & 0.08 & 0.04 & 0.00 \\
\hline Total & 98.71 & 98.41 & 99.95 & 99.95 & 100.21 & 99.13 & 98.97 \\
\hline \multicolumn{8}{|c|}{ Structural Composition: (3 Cations) } \\
\hline $\mathrm{Si}$ & 0.003 & 0.004 & 0.004 & 0.001 & 0.003 & 0.003 & 0.004 \\
\hline $\mathrm{Al}$ & 0.285 & 0.234 & 0.236 & 0.371 & 0.221 & 0.421 & 0.249 \\
\hline $\mathrm{Ti}$ & 0.003 & 0.002 & 0.001 & 0.003 & 0.002 & 0.003 & 0.001 \\
\hline $\mathrm{Fe}^{2+}$ & 0.529 & 0.513 & 0.700 & 0.644 & 0.691 & 0.531 & 0.564 \\
\hline $\mathrm{Fe}^{3+}$ & 0.129 & 0.037 & 0.067 & 0.205 & 0.085 & 0.176 & 0.068 \\
\hline $\mathrm{Mn}$ & 0.011 & 0.012 & 0.014 & 0.011 & 0.015 & 0.010 & 0.011 \\
\hline $\mathrm{Mg}$ & 0.465 & 0.481 & 0.290 & 0.348 & 0.206 & 0.463 & 0.430 \\
\hline $\mathrm{Cr}$ & 1.572 & 1.717 & 1.686 & 1.416 & 1.686 & 1.392 & 1.673 \\
\hline $\mathrm{Ca}$ & 0.001 & & & 0.001 & 0.003 & 0.001 & \\
\hline $\mathrm{Cr} \#$ & 84.7 & 88.0 & 87.7 & 79.2 & 88.4 & $\begin{array}{l}76.8 \\
\end{array}$ & 87.0 \\
\hline $\mathrm{Mg} \#$ & 46.8 & 48.4 & 29.3 & 35.1 & 30.0 & 46.6 & 43.3 \\
\hline Fe\# & 6.5 & 1.9 & 3.4 & 10.3 & 4.3 & 8.8 & 3.4 \\
\hline
\end{tabular}

$\mathrm{Fe}$ analyzed as $\mathrm{FeO}$, distributed on the basis of structural formula calculation. ${ }^{\mathrm{a}}$ - included in clinoenstatite

b- core of groundmass crystal

c- rim of groundmass crystal

d- included in bronzite

e- groundmass crystal 
Table 5 - Low-Ca Pyroxene Analyses

\begin{tabular}{|c|c|c|c|c|c|c|c|c|c|}
\hline & MD-94 & MD-58 ${ }^{\mathrm{a}}$ & MD-58 & MD-97 & MD-94 & MD- $52^{c}$ & MD- $58^{\mathrm{c}}$ & MD-114 & MD-58 \\
\hline $\mathrm{SiO}_{2}$ & 58.05 & 57.18 & 64.44 & 56.98 & 66.36 & 56.45 & 56.56 & 57.00 & 53.79 \\
\hline $\mathrm{Al}_{2} \mathrm{O}_{3}$ & 0.25 & 0.21 & 0.79 & 0.51 & 0.75 & 0.69 & 0.37 & 0.75 & 1.73 \\
\hline $\mathrm{FeO}$ & 6.65 & 5.59 & 13.10 & 8.66 & 9.36 & 8.75 & 7.55 & 8.29 & 15.04 \\
\hline $\mathrm{Fe}_{2} \mathrm{O}_{3}$ & 0. & 0. & 0.92 & 0. & 0. & 0. & 0. & 0. & 0. \\
\hline $\mathrm{MgO}$ & 33.70 & 34.92 & 27.47 & 31.66 & 30.70 & 31.04 & 32.87 & 32.33 & 24.32 \\
\hline $\mathrm{MnO}$ & 0.21 & 0.09 & 0.28 & 0.20 & 0.21 & 0.21 & 0.15 & 0.18 & 0.28 \\
\hline $\mathrm{TiO}_{2}$ & 0.01 & 0. & 0.04 & 0. & 0. & 0.03 & 0.02 & 0.02 & 0.09 \\
\hline $\mathrm{Cr}_{2} \mathrm{O}_{3}$ & 0.38 & 0.21 & 0.12 & 0.28 & 0.38 & 0.42 & 0.33 & 0.56 & 0.07 \\
\hline $\mathrm{CaO}$ & 0.32 & 0.23 & 2.11 & 1.39 & 2.33 & 1.69 & 1.01 & 1.35 & 4.16 \\
\hline $\mathrm{Na}_{2} \mathrm{O}$ & 0. & 0. & 0.02 & 0. & 0. & 0.02 & 0.04 & 0. & 0.03 \\
\hline SUM & 99.57 & 98.43 & 99.29 & 99.68 & 100.09 & 99.30 & 99.20 & 100.48 & 99.51 \\
\hline \multicolumn{10}{|c|}{ Structural Composition } \\
\hline $\mathrm{Si}$ & 2.010 & 1.994 & 1.968 & 1.996 & 1.980 & 1.989 & 1.984 & 1.980 & 1.963 \\
\hline AlIV & 0. & 0.006 & 0.032 & 0.004 & 0.020 & 0.011 & 0.015 & 0.020 & 0.037 \\
\hline AlVI & 0.010 & 0.003 & 0.002 & 0.017 & 0.011 & 0.018 & 0. & 0.011 & 0.038 \\
\hline $\mathrm{Fe}^{2+}$ & 0.193 & 0.163 & 0.396 & 0.254 & 0.275 & 0.258 & 0.222 & 0.241 & 0.459 \\
\hline $\mathrm{Fe}^{3+}$ & 0. & 0. & 0.025 & 0. & 0. & 0. & 0.008 & 0. & 0. \\
\hline $\mathrm{Mg}$ & 1.739 & 1.815 & 1.480 & 1.653 & 1.608 & 1.630 & 1.718 & 1.674 & 1.323 \\
\hline $\mathrm{Mn}$ & 0.006 & 0.003 & 0.009 & 0.006 & 0.006 & 0.006 & 0.004 & 0.005 & 0.009 \\
\hline $\mathrm{Ti}$ & 0.000 & 0. & 0.001 & 0. & 0. & 0.001 & 0.001 & 0.001 & 0.002 \\
\hline $\mathrm{Cr}$ & 0.010 & 0.006 & 0.003 & 0.008 & 0.011 & 0.012 & 0.009 & 0.015 & 0.002 \\
\hline $\mathrm{Ca}$ & 0.012 & 0.009 & 0.082 & 0.052 & 0.088 & 0.064 & 0.038 & 0.050 & 0.163 \\
\hline $\mathrm{Na}$ & 0 & 0. & 0.001 & 0. & 0. & 0.001 & 0.003 & 0. & 0.002 \\
\hline SUM & 3.980 & 3.998 & 4.000 & 3.990 & 3.999 & 3.990 & 4.001 & 3.997 & 3.997 \\
\hline
\end{tabular}

Fe analyzed as $\mathrm{FeO}$, distributed on the basis or structural formula correction. ${ }^{\mathrm{a}}$ - clinoenstatite ${ }^{\mathrm{b}}$ - bronzite rim on clinoenstatite ${ }^{\mathrm{c}}$ - bronzite ${ }^{\mathrm{d}}$ - pigeonite $^{-}$ 
Table 5 (cont.)

\begin{tabular}{|c|c|c|c|c|c|c|c|}
\hline & $M D-43^{\mathrm{e}}$ & MD- $103^{\mathrm{e}}$ & $M D-65^{\mathrm{e}}$ & $M D-65^{f}$ & MD-119 & MD- $121^{\mathrm{g}}$ & MD- $121^{\mathrm{g}}$ \\
\hline $\mathrm{SiO}_{2}$ & 52.26 & 53.64 & 53.68 & 50.55 & 49.61 & 50.80 & 49.23 \\
\hline $\mathrm{Al}_{2} \mathrm{O}_{3}$ & 0.65 & 1.12 & 1.38 & 0.57 & 0.46 & 0.50 & 0.37 \\
\hline $\mathrm{FeO}$ & 26.70 & 24.56 & 18.47 & 29.51 & 31.92 & 31.15 & 36.61 \\
\hline $\mathrm{Fe}_{2} \mathrm{O}_{3}$ & 0.14 & 0. & 0. & 0.71 & 0.46 & 0. & 0. \\
\hline $\mathrm{MgO}$ & 18.31 & 19.77 & 24.15 & 16.13 & 14.07 & 12.49 & 7.84 \\
\hline $\mathrm{MnO}$ & 0.70 & 0.51 & 0.38 & 0.87 & 0.96 & 0.98 & 1.08 \\
\hline $\mathrm{TiO}_{2}$ & 0.04 & 0.08 & 0.07 & 0.09 & 0.13 & 0.10 & 0.13 \\
\hline $\mathrm{Cr}_{2} \mathrm{O}_{3}$ & 0. & 0. & 0. & 0. & 0. & 0. & 0.03 \\
\hline $\mathrm{CaO}$ & 1.83 & 1.87 & 1.63 & 1.53 & 1.48 & 3.77 & 3.87 \\
\hline $\mathrm{Na}_{2} \mathrm{O}$ & 0.03 & 0. & 0. & 0. & 0. & 0.05 & 0.03 \\
\hline SUM & 100.66 & 101.55 & 99.76 & 99.96 & 99.09 & 99.84 & 99.19 \\
\hline \multicolumn{8}{|c|}{ Structural Composition } \\
\hline $\mathrm{Si}$ & 1.983 & 1.989 & 1.971 & 1.968 & 1.974 & 2.002 & 2.013 \\
\hline AlIV & 0.017 & 0.011 & 0.029 & 0.026 & 0.022 & 0. & 0. \\
\hline AlVI & 0.012 & 0.038 & 0.031 & 0. & 0. & 0.023 & 0.018 \\
\hline $\mathrm{Fe}^{2+}$ & 0.848 & 0.762 & 0.567 & 0.961 & 1.062 & 1.027 & 1.252 \\
\hline $\mathrm{Fe}^{3+}$ & 0.004 & 0. & 0. & 0.021 & 0.014 & 0. & 0. \\
\hline $\mathrm{Mg}$ & 1.036 & 1.092 & 1.321 & 0.936 & 0.834 & 0.734 & 0.478 \\
\hline $\mathrm{Mn}$ & 0.023 & 0.016 & 0.012 & 0.029 & 0.032 & 0.033 & 0.037 \\
\hline $\mathrm{Ti}$ & 0.001 & 0.002 & 0.002 & 0.003 & 0.004 & 0.003 & 0.004 \\
\hline $\mathrm{Cr}$ & 0. & 0. & 0. & 0. & 0. & 0. & 0.001 \\
\hline $\mathrm{Ca}$ & 0.074 & 0.074 & 0.064 & 0.064 & 0.063 & 0.159 & 0.170 \\
\hline $\mathrm{Na}$ & 0.002 & 0. & 0. & 0. & 0. & 0.004 & 0.002 \\
\hline SUM & 4.000 & 3.984 & 3.997 & 4.006 & 4.005 & 3.985 & 3.975 \\
\hline
\end{tabular}

e- hypersthene ${ }^{\mathrm{f}}$ - ferrohypersthene ${ }^{\mathrm{g}}$ - ferropigeonite 
Table 6 - High-Ca Pyroxene Analyses

\begin{tabular}{|c|c|c|c|c|c|c|c|c|c|c|}
\hline & MD-94 & MD-94 & MD-52 & MD-114 & MD-43 & MD-103 & MD-121 & MD-65 & MD-65 & MD-119 \\
\hline $\mathrm{SiO}_{2}$ & 53.76 & 52.62 & 53.46 & 53.13 & 52.11 & 52.59 & 50.52 & 52.35 & 51.88 & 50.56 \\
\hline $\mathrm{Al}_{2} \mathrm{O}_{3}$ & 1.33 & 2.25 & 1.20 & 2.18 & 1.47 & 1.29 & 1.02 & 0.91 & 3.01 & 1.12 \\
\hline $\mathrm{FeO}$ & 9.29 & 6.76 & 7.75 & 8.15 & 14.87 & 15.26 & 21.04 & 15.87 & 9.36 & 13.83 \\
\hline $\mathrm{Fe}_{2} \mathrm{O}_{3}$ & 0. & 0.71 & 0. & 0. & 0.94 & 0. & 0.24 & 0. & 0.81 & 2.02 \\
\hline $\mathrm{MgO}$ & 19.04 & 16.80 & 17.00 & 16.43 & 12.34 & 12.41 & 8.88 & 11.21 & 15.72 & 11.43 \\
\hline $\mathrm{MnO}$ & 0.23 & 0.18 & 0.24 & 0.21 & 0.42 & 0.39 & 0.60 & 0.48 & 0.21 & 0.49 \\
\hline $\mathrm{TiO}_{2}$ & 0.02 & 0.06 & 0.06 & 0.08 & 0.12 & 0.10 & 0.17 & 0.15 & 0.15 & 0.14 \\
\hline $\mathrm{Cr}_{2} \mathrm{O}_{3}$ & 0.06 & 0.16 & 0.26 & 0.24 & 0.03 & 0. & 0. & 0.02 & 0.10 & 0. \\
\hline $\mathrm{CaO}$ & 15.28 & 19.79 & 19.53 & 20.15 & 18.89 & 18.95 & 17.44 & 19.76 & 18.61 & 19.77 \\
\hline $\mathrm{Na}_{2} \mathrm{O}$ & 0.06 & 0.16 & 0.13 & 0. & 0.20 & 0.19 & 0.16 & 0.23 & 0.16 & 0.21 \\
\hline SUM & 99.07 & 99.48 & 99.63 & 100.57 & 101.39 & 101.18 & 100.07 & 100.98 & 100.01 & 99.56 \\
\hline \multicolumn{11}{|c|}{ Structural Composition } \\
\hline $\mathrm{Si}$ & 1.982 & 1.943 & 1.974 & 1.949 & 1.958 & 1.976 & 1.974 & 1.984 & 1.923 & 1.945 \\
\hline AlIV & 0.018 & 0.057 & 0.026 & 0.051 & 0.042 & 0.024 & 0.026 & 0.016 & 0.077 & 0.051 \\
\hline AlVI & 0.040 & 0.041 & 0.026 & 0.043 & 0.023 & 0.033 & 0.021 & 0.024 & 0.055 & 0. \\
\hline $\mathrm{Fe}^{2+}$ & 0.286 & 0.209 & 0.239 & 0.250 & 0.467 & 0.480 & 0.688 & 0.503 & 0.290 & 0.445 \\
\hline $\mathrm{Fe}^{3+}$ & 0. & 0.020 & 0. & 0. & 0.027 & 0. & 0.007 & 0. & 0.023 & 0.058 \\
\hline $\mathrm{Mg}$ & 1.046 & 0.924 & 0.935 & 0.898 & 0.691 & 0.695 & 0.517 & 0.633 & 0.868 & 0.655 \\
\hline $\mathrm{Mn}$ & 0.007 & 0.006 & 0.008 & 0.007 & 0.013 & 0.012 & 0.020 & 0.015 & 0.007 & 0.016 \\
\hline $\mathrm{Ti}$ & 0.001 & 0.002 & 0.002 & 0.002 & 0.003 & 0.003 & 0.005 & 0.004 & 0.004 & 0.004 \\
\hline $\mathrm{Cr}$ & 0.002 & 0.005 & 0.008 & 0.007 & 0.001 & 0 & 0 & 0.001 & 0.003 & 0. \\
\hline $\mathrm{Ca}$ & 0.604 & 0.783 & 0.773 & 0.792 & 0.760 & 0.763 & 0.730 & 0.802 & 0.739 & 0.815 \\
\hline $\mathrm{Na}$ & 0.004 & 0.011 & 0.009 & 0. & 0.015 & 0.014 & 0.012 & 0.017 & 0.011 & 0.016 \\
\hline SUM & 3.990 & 4.000 & 3.999 & 3.999 & 4.000 & 4.000 & 4.000 & 4.000 & 4.000 & 4.004 \\
\hline
\end{tabular}

Fe analyzed as $\mathrm{FeO}$, distributed on the basis of structural formula correction. MD-121 sample is ferroaugite; all other samples are augite 
Table 7 - Plagioclase Feldspar Analyses

\begin{tabular}{|c|c|c|c|c|c|c|c|c|c|}
\hline & MD-114 & MD-65c & MD-65r & D-39c & D-39r & MD-118c & MD-118r & MD-119c & MD-119r \\
\hline $\mathrm{SiO}_{2}$ & 47.53 & 52.27 & 55.19 & 56.65 & 50.11 & 50.23 & 55.61 & 55.88 & 55.79 \\
\hline $\mathrm{TiO}_{2}$ & 0.00 & 0.00 & 0.00 & 0.01 & 0.02 & 0.02 & 0.01 & 0.00 & 0.00 \\
\hline $\mathrm{Al}_{2} \mathrm{O}_{3}$ & 32.26 & 29.76 & 27.82 & 27.01 & 30.46 & 30.98 & 27.15 & 27.36 & 27.21 \\
\hline $\mathrm{FeO}$ & 0.93 & 0.60 & 0.60 & 0.47 & 0.91 & 0.98 & 0.77 & 0.47 & 0.45 \\
\hline $\mathrm{CaO}$ & 16.57 & 14.13 & 11.40 & 9.74 & 14.87 & 14.24 & 10.28 & 10.44 & 10.47 \\
\hline $\mathrm{Na}_{2} \mathrm{O}$ & 1.86 & 4.21 & 5.28 & 5.55 & 2.56 & 3.28 & 5.68 & 5.54 & 5.59 \\
\hline $\mathrm{K}_{2} \mathrm{O}$ & 0.03 & 0.05 & 0.06 & 0.07 & 0.03 & 0.04 & 0.08 & 0.06 & 0.08 \\
\hline Total & 99.18 & 101.05 & 100.40 & 99.50 & 99.00 & 99.80 & 99.63 & 99.76 & 99.58 \\
\hline \multicolumn{10}{|c|}{ Structural Composition (8 Oxygens) } \\
\hline $\mathrm{Si}$ & 2.205 & 2.363 & 2.488 & 2.555 & 2.313 & 2.302 & 2.521 & 2.523 & 2.525 \\
\hline $\mathrm{Al}$ & 1.764 & 1.586 & 1.478 & 1.436 & 1.657 & 1.673 & 1.451 & 1.456 & 1.452 \\
\hline $\mathrm{Ti}$ & 0.000 & 0.000 & 0.000 & 0.000 & 0.001 & 0.001 & 0.000 & 0.000 & 0.000 \\
\hline $\mathrm{Fe}$ & 0.036 & 0.023 & 0.023 & 0.018 & 0.035 & 0.038 & 0.029 & 0.018 & 0.017 \\
\hline $\mathrm{Na}$ & 0.168 & 0.369 & 0.462 & 0.485 & 0.229 & 0.291 & 0.499 & 0.485 & 0.490 \\
\hline $\mathrm{Ca}$ & 0.823 & 0.684 & 0.551 & 0.471 & 0.735 & 0.609 & 0.499 & 0.505 & 0.507 \\
\hline $\mathrm{K}$ & 0.002 & 0.003 & 0.003 & 0.004 & 0.002 & 0.003 & 0.005 & 0.003 & 0.004 \\
\hline
\end{tabular}

c- phenocryst core analysis

$\mathrm{r}$ - phenocryst rim analysis 
Table 8 - Magnetite Analyses

\begin{tabular}{|l|l|l|l|l|l|}
\hline & MD-65 & D-39 & MD-119 & MD-120 & MD-121 \\
\hline $\mathrm{SiO}_{2}$ & 0.30 & 0.51 & 0.49 & 0.21 & 0.51 \\
\hline $\mathrm{Al}_{2} \mathrm{O}_{3}$ & 1.98 & 2.41 & 2.15 & 2.19 & 2.71 \\
\hline $\mathrm{TiO}_{2}$ & 7.36 & 7.05 & 8.61 & 8.62 & 8.31 \\
\hline $\mathrm{FeO}$ & 35.02 & 36.23 & 38.48 & 38.20 & 37.86 \\
\hline $\mathrm{Fe}_{2} \mathrm{O}_{3}$ & 52.72 & 51.24 & 48.32 & 49.03 & 47.60 \\
\hline $\mathrm{MnO}$ & 0.22 & 0.21 & 0.26 & 0.25 & 0.23 \\
\hline $\mathrm{MgO}$ & 2.16 & 1.25 & 0.68 & 0.67 & 0.77 \\
\hline $\mathrm{Cr}_{2} \mathrm{O}_{3}$ & 0.02 & 0.12 & 0.09 & 0.08 & 0.05 \\
\hline $\mathrm{CaO}$ & 0.00 & 0.03 & 0.00 & 0.00 & 0.04 \\
\hline $\mathrm{Total}$ & 99.80 & 99.05 & 99.07 & 99.24 & 98.08 \\
\hline \multicolumn{2}{|l|}{ Structural Composition (3 Cations) } & & \\
\hline $\mathrm{Si}$ & 0.011 & 0.019 & 0.019 & 0.008 & 0.019 \\
\hline $\mathrm{Al}$ & 0.087 & 0.107 & 0.096 & 0.098 & 0.122 \\
\hline $\mathrm{Ti}$ & 0.206 & 0.200 & 0.245 & 0.245 & 0.238 \\
\hline $\mathrm{Fe}$ & 1.090 & 1.141 & 1.217 & 1.207 & 1.204 \\
\hline $\mathrm{Fe}$ & 1.478 & 1.452 & 1.375 & 0.008 & 1.363 \\
\hline $\mathrm{Mn}$ & 0.007 & 0.007 & 0.008 & 0.038 & 0.007 \\
\hline $\mathrm{Mg}$ & 0.120 & 0.070 & 0.038 & 0.002 & 0.044 \\
\hline $\mathrm{Cr}$ & 0.000 & 0.001 & 0.000 & 0.000 & 0.002 \\
\hline $\mathrm{Ca}$ & & 0.004 & & 0.002 \\
\hline $\mathrm{Fe}$ & & & & \\
\hline
\end{tabular}

Fe analyzed as $\mathrm{FeO}$, distributed on the basis of structural formula calculation. 
Table 9 - Geothermometry Data

\begin{tabular}{|c|c|c|c|c|c|}
\hline Rock Type & Sample \# & $\begin{array}{l}\text { Wells } \\
(1977)\end{array}$ & $\begin{array}{l}\text { Lindsley and Anderson } \\
\text { (1983) }\end{array}$ & Kretz (1982) & Ishii (1980) \\
\hline \multirow[t]{2}{*}{ Boninite } & MD-94 & 1269 & $1260_{\mathrm{cpx}}, 1250_{\mathrm{opx}}$ & 1287 & \\
\hline & MD-52 & 1101 & $1080_{\mathrm{cpx}}, 1120_{\mathrm{opx}}$ & 1131 & \\
\hline \multirow{2}{*}{$\begin{array}{l}\text { Bronzite } \\
\text { Andesite }\end{array}$} & MD-114 & 1072 & $1080_{\mathrm{cpx}}, 1040_{\mathrm{opx}}$ & 1097 & \\
\hline & MD-58 & & & & 1145 \\
\hline \multirow[t]{2}{*}{ Dacite } & MD-43 & 998 & $1015_{\mathrm{cpx}}, 1000_{\mathrm{opx}}$ & 1013 & \\
\hline & MD-103 & 991 & $960_{\mathrm{cpx}}, 1010_{\mathrm{opx}}$ & 1020 & \\
\hline \multirow{2}{*}{$\begin{array}{l}\text { Quartz } \\
\text { Dacite }\end{array}$} & MD-65 & & & $835-1135$ & \\
\hline & D-39 & & & $795-1188$ & \\
\hline Rhyolite & MD-119 & 966 & $850_{\mathrm{cpx}}, 850_{\mathrm{opx}}$ & 861 & \\
\hline
\end{tabular}


Table 10 - Crystal Fractionation Modeling

\begin{tabular}{|c|c|c|c|c|c|c|c|}
\hline \multirow{2}{*}{$\begin{array}{l}\text { Start - End } \\
\text { Compositions }\end{array}$} & \multicolumn{6}{|c|}{ Phases Crystallized } & \multirow[t]{2}{*}{ Sum $r^{2}$} \\
\hline & $\% \mathrm{ol}$ & $\%$ opx & $\% \mathrm{cpx}$ & $\%$ plag & $\% \mathrm{mt}$ & $\%$ liquid & \\
\hline MD-94 - MD-114 & 12.72 & 0.92 & 10.79 & & & 75.57 & 0.02 \\
\hline MD-54 - MD-114 & 4.46 & 22.41 & 4.40 & & & 68.73 & 0.19 \\
\hline $\begin{array}{l}\text { MD-114 - MD-43 } \\
\text { (MD-54 - MD-43) }\end{array}$ & 4.46 & $\begin{array}{l}15.12 \\
32.80\end{array}$ & $\begin{array}{l}10.86 \\
11.86\end{array}$ & $\begin{array}{l}19.53 \\
13.43\end{array}$ & $\begin{array}{l}3.03 \\
2.08\end{array}$ & $\begin{array}{l}51.46 \\
35.37\end{array}$ & 0.08 \\
\hline $\begin{array}{l}\text { MD-43 - MD-119 } \\
\text { (MD-54 - MD-119) }\end{array}$ & 4.46 & $\begin{array}{l}4.60 \\
34.43\end{array}$ & $\begin{array}{l}1.69 \\
12.46\end{array}$ & $\begin{array}{l}14.86 \\
18.69\end{array}$ & $\begin{array}{l}2.69 \\
3.03\end{array}$ & $\begin{array}{l}76.16 \\
26.94\end{array}$ & 0.20 \\
\hline
\end{tabular}


Table 11 - Crystal Fractionation Models

\begin{tabular}{|l|l|l|l|}
\hline & This Study & $\begin{array}{l}\text { Bloomer and Hawkins } \\
(1987)\end{array}$ & Meijer (1983) \\
\hline $\mathrm{SiO}_{2}$ & $58.2-77.0$ & $57.1-67.5$ & $57.5-81.4$ \\
\hline $\mathrm{MgO}$ & $15.5-0.4$ & $15.3-3.6$ & $6.4-0.1$ \\
\hline $\mathrm{K}_{2} \mathrm{O}$ & $0.4-1.8 \quad$ & $1.0-1.4$ & $0.4-1.7$ \\
\hline \multicolumn{4}{|l|}{ Phases Crystallized } \\
\hline Olivine & 4.5 & 13.54 & \\
\hline Orthopyroxene & 34.4 & 21.98 & 22.0 \\
\hline Clinopyroxene & 12.5 & 5.43 & 13.6 \\
\hline Plagioclase & 18.7 & 9.72 & 39.0 \\
\hline Magnetite & 3.0 & & 2.3 \\
\hline Ilmenite & & & 0.4 \\
\hline Apatite & & & 0.2 \\
\hline Liquid & 27.0 & 46.7 & 22.3 \\
\hline
\end{tabular}

